\title{
LAS EMISIONES ARÁBIGAS HASTA LA REFORMA MONETARIA DE ABD AL-MALIK
}

\author{
ARABIC ISSUES UP TO AND INCLUDING \\ ABD AL-MALIK'S MONETARY REFORM
}

\author{
María del Mar ROYO MARTÍNEZ \\ Universidad Complutense de Madrid \\ A la memoria de mi apreciada amiga y maestra, \\ la doctora María Ruiz Trapero
}

Resumen: En el presente artículo se analizan las emisiones arábigas hasta la reforma monetaria de Abd al-Malik del año 77 H. / 696 d. C., partiendo de una revisión de lo publicado hasta el momento sobre todos los aspectos concernientes a ellas.

Palabras clave: Bizantino, Árabe, Árabe-bizantino, Dracma Sasánida, Dracma Árabe-Sasánida, Dinar, Dírham, Felús, Abd al-Malik.

\begin{abstract}
The purpose of this article is to analize arabic issues, up to and including the Abd al-Malik's Monetary Reform of the 77 AH / 696 AD, starting with a review of all the works published up to date on every aspect of them.
\end{abstract}

Keywords: Byzantine, Arab, Arab-bizantine, Sasanian Drachm, ArabSasanian Drachm, Dinar, Dirham, fals, Abd al-Malik.

\section{LAS EMISIONES DE LOS CALIFAS ORTODOXOS}

Mucho antes de que el califa Abd al-Malik creara el sistema monetario propio del mundo islámico en su reforma monetaria efectuada entre el $77 \mathrm{H}$. / $696 \mathrm{~d}$. C. y el 79 H. / 698 d. C., los árabes emitieron monedas de imitación basadas en las acuñaciones de los diferentes territorios que iban conquistando. Las emisiones más antiguas se iniciaron hacia el segundo cuarto del siglo VII d. C., bajo el segundo de los Califas Ortodoxos o Rashidun ${ }^{1}$, Omar (13-23 H. / 634-644 d. C.), y consistieron en piezas de bronce de imitación bizantina. El gobierno de Omar coincidió cronológicamente con el del Emperador bizantino Heraclio I (610-641

${ }^{1}$ Rashidun es un término utilizado en Islam para referirse a los cuatro primeros califas (Abu Bakr, Omar, Otmán y Alí) del Califato Ortodoxo, el primer Califato fundado tras la muerte de Mahoma. 
d. C.) y posteriormente con el de Constante II (641-668 d. C.) y con el del rey Sasánida Yazdgerd III (632-651 d. C.) nieto de Cosroes II.

Unificada ya la Península arábiga, durante su califato los árabes realizaron las conquistas más importantes sobre los bizantinos. En el año 14 H. / 635 d. C. la Batalla de Yarmuk permitió la posterior conquista árabe de la provincia de Siria en el 16 H. / 637 d. C. y en el 21 H. / 642 d. C. ocuparon también Palestina y Egipto, así como Irak tras la Batalla de Nehavend. El rey sasánida Yazdgerd III (632-651 d. C.), incapaz de reunir un nuevo ejército se dio a la fuga tras dicha batalla, terminado así en Irak la resistencia persa, aunque las autoridades locales continuarían ofreciendo una esporádica oposición.

Las piezas de imitación bizantina, los denominados follis arabe-bizantinos, mostraban imágenes tomadas de las monedas de los emperadores Heraclio I y Constante II, y posteriormente de Constantino IV, a las que más adelante se añadirían otras originales impuestas por el nuevo régimen islámico. En el anverso llevaban la representación frontal del emperador bizantino, sólo o acompañado, y en el reverso la gran marca de valor $\mathrm{M}$ o m (equivalente a 40 nummi). El problema que plantean estas series es bastante complejo, dado que ninguna de las piezas ofrece una datación clara y las más antiguas ni siquiera muestran su respectiva marca del taller emisor. Por otra parte, muchas de ellas muestran diseños bastante burdos, una mala factura y leyendas confusas o indescifrables.

Los intentos de clasificación y ordenación de los bronces emitidos hasta la Reforma de Abd al-Malik, han sido objeto de numerosos estudios y publicaciones en las últimas décadas. A pesar de ello, por el momento sólo se ha conseguido hacer una clasificación aproximada del numerario y no exenta de algunas variaciones entre las fechas propuestas. Aunque en 1994 Michael Bates $^{2}$ concluyó sus investigaciones señalando que la mayoría de las piezas árabe-bizantinas se emitieron hacia finales del siglo VII d. C. y durante un corto espacio de tiempo, las últimas teorías parecen indicar lo contrario. Autores como Henri Pottier ${ }^{3}$ o como Clive $\mathrm{Foss}^{4}$, han propuesto recientemente que los bronces árabe-bizantinos se emitieron a lo largo de bastante tiempo, durante varias décadas.

\footnotetext{
${ }^{2}$ Michael BATES, "Byzantine Coinage and Its Imitations, Arab Coinage and Its Imitations: Arab-byzantine Coinage”, Aram, 6 (1994), pp. 381-403.

${ }^{3}$ Henri POTTIER, Ingrid SCHULZE, Wolfang SCHULZE, "Pseudo-Byzantine Coinage in Siria under Arab Rule (638-c. 670), classification and dating”, Revue Belge de Numismatique, Vol. 154 (2008), pp. 87-155.

${ }^{4}$ Clive FOSS, Arab-Byzantine Coins. An introduction with a catalogue of the Dumbarton Oaks Collection, Harvard University Press, 2008.
} 


\section{MARÍA DEL MAR RoYo MARTÍNEZ \\ LAS EMISIONES ARÁBIGAS HASTA LA REFORMA MONETARIA DE ABD AL-MALIK.}

En la actualidad las piezas se suelen clasificar por orden cronológico, de la siguiente manera:

- Los bronces más antiguos serían las denominadas "monedas de imitación completa", que son aquellas que siguen fielmente los diseños y las leyendas originales de las monedas a las que imitan, aunque sus diseños son más toscos.

- Las siguientes series serían las denominadas "monedas derivativas", las cuales mantienen los diseños originales (el busto del emperador el anverso y la marca $\mathrm{M} \mathrm{o} \mathrm{m}$ en el reverso), pero suelen presentar variaciones en éstos. Sus leyendas, a menudo confusas, están escritas normalmente en griego, aunque a veces pueden figurar en árabe. Las "monedas de imitación completa" y "las derivativas", se conocen también en el ámbito anglosajón, como "monedas pseudobizantinas".

- Las "monedas bilingües", aquellas que también conservan los diseños originales, pero que muestran ahora su respectiva marca del taller islámico. Sus leyendas están escritas en griego, griego-árabe, o sólo en árabe.

-Finalmente estarían las "monedas del califa de pie", aquellas que muestran en anverso la figura del califa de pie y frente y cuyas leyendas figuran íntegramente en árabe.

Las emisiones más antiguas dentro de las "monedas de imitación completa", pudieron efectuarse según Henri Pottier ${ }^{5}$ entre los años 17 H. / 638 d. C. y 22 H. / $643 \mathrm{~d}$. C. en algún lugar de Siria. Se trataba de follis que imitaban los producidos en la isla de Chipre por el emperador Heraclio I (figs. 1 y 2), y que llevaban en su anverso la figura del propio emperador, junto con la de Heraclio Constantino y de Martina, y en el reverso la gran letra M, con la marca de ceca de Chipre: КҮПP en el exergo. Sin embargo el mayor volumen de monedas de "imitación completa" y de monedas "derivativas" (figs. 3 y 4) se emitiría en Siria y en Egipto entre los años 26 H. / 647 d. C, y 50 H. / 670 d. C. aproximadamente.

Los territorios de Siria habían sido divididos, según se cree, por Omar, en cuatro grandes provincias o distritos militares, denominados jund, o ajnad (en plural). Al sureste se encontraba el jund Damasco, en el norte el jund Homs, en el centro el jund Al-Urdunn, y en el sur el jund Filastin (Palestina), pero las monedas no llevarían en este momento ni fechas ni marcas de ceca árabes, de lo que se deriva su enorme complejidad.

\footnotetext{
${ }^{5}$ Henri POTTIER, Ingrid SCHULZE, Wolfang SCHULZE, "Pseudo-Byzantine Coinage...", op. cit., p. 97.
} 


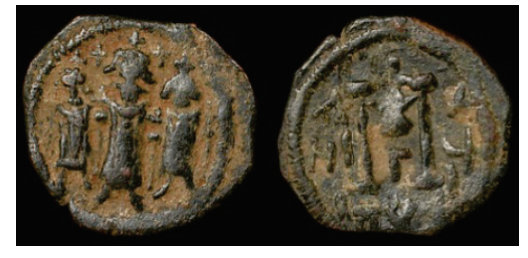

Fig. 1.

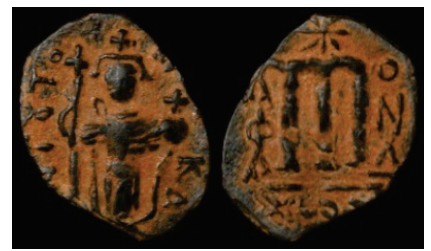

Fig. 3.

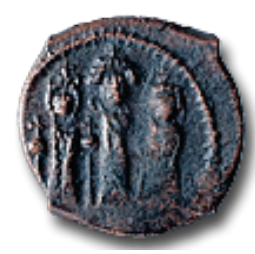

Fig. 2.

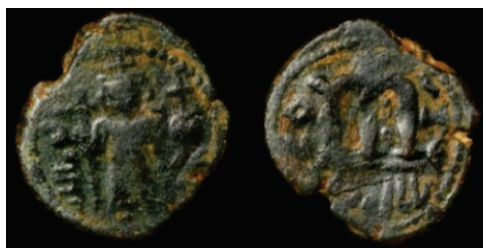

Fig. 4.

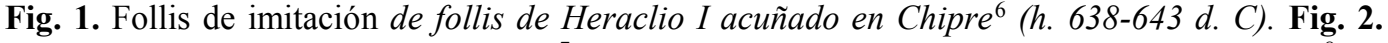
Follis de Heraclio I acuñado en Chipre ${ }^{7}$. Fig. 3. Follis de imitación de follis de Constancio II ${ }^{8}(h$. 647-6670 d. C.), emitido en ceca incierta de Siria. Fig. 4. Follis de imitación de follis de Constancio $I I^{9}$ (h. 647-670 d. C.), acuñado probablemente al norte de Palestina. La leyenda del anverso y del reveso (en árabe) dice: "al-wafa-Ullah" (la buena fe es con Allah).

En el 23 H. / 644 d. C. Omar fue asesinado siendo sucedido por Otmán (2335 H. / 644-656 d. C.). Por aquel entonces la expansión árabe en Irán llegaba hasta Ispahán, Shiraz (Pars), y Hamadán. Durante su califato, además de continuar las series de follis árabe-bizantinos de imitación, parece que algunas ciudades de Irán e Irak comenzaron a acuñar también dracmas de imitación Sasánida, semejantes a las que se habían estado labrando allí hasta entonces, pero con un estilo algo más tosco. En su anverso mostraban el busto del rey persa, acompañado del nombre de Cosroes II o de Yazdgard III en palhevi, y en el reverso un altar con fuego flanqueado por dos asistentes, con el año del reinado a la izquierda, y el nombre de la ceca a la derecha. La presencia del altar con fuego estaba claramente relacionada con el culto a Zoroastro. En todas las ciudades importantes del Imperio Sasánida se mantenía de hecho un templo del fuego y en cada uno de ellos se veneraba a una llama sagrada de la que se creía que había sido encendida desde los cielos y se mantenía perpetuamente encendida por los sacerdotes. De ella se decía que era

6 http://www.metmuseum.org/exhibitions/view?exhibitionId=\%7b60853040-AE7E-4162-8F A7-525505D6B633\%7d\&oid=479416\&pkgids=186\&pg=3\&rpp=50\&pos $=104 \& f \mathrm{ft}=*$ [consultado el 14/12/2014].

${ }^{7} \mathrm{https}$ ://www.mnh.si.edu/exhibits/cyprus/byzantine-coins.html [consultado el 27/02/2015].

$8 \mathrm{http}: / /$ www.metmuseum.org/exhibitions/view? exhibitionId=\%7b60853040-AE7E-4162-8F A7-525505D6B633\%7d\&oid=479418\&pkgids=186\&pg=3\&rpp=50\&pos $=106 \& \mathrm{ft}=* \quad$ [consultado el 08/01/2015].

9 http://www.metmuseum.org/exhibitions/objects? exhibitionId=\%7b60853040-AE7E-41628F A7-525505D6B633\%7d\&oid=479419\&pg=3\&rpp=50\&pos=107\&ft=* [consultado el 14/12/ 2014]. 
"inextinguible". Aunque al principio las dracmas fueron de imitación completa ${ }^{10} \mathrm{y}$ con todas sus leyendas íntegramente en palhevi, en el margen exterior del anverso se empezaron a añadir en la mayoría de ellas breves leyendas en escritura arábiga, con intencionalidad propagandística sobre la religión del Islam. Se añadieron así frases como:"bismi Allāh " (en el nombre de Allah), "bismi Allāh rabbi" (en el nombre de Allah, mi Señor), "lillah al-hamd" (Allah sea alabado), "lillah" (para Allah), o palabras como: "tayyib" (bueno).

Al igual que en las propias emisiones sasánidas, la mayoría de ellas llevaban marca de ceca y el año de reinado del rey Sasánida. Las denominadas dracmas del tipo Yazdgard III (las que imitan las de este rey) llevan además siempre el año 20 de su Era (correspondiente al 651/652 d. C.). Dicho año (el último de su reinado), permaneció curiosamente "congelado" en las monedas unos quince años o algo más, sin que se conozcan los motivos. Por lo tanto estas dracmas de imitación se emitieron entre el 30 H. / 651 d. C. y el 50 H. / 670 d. C. aproximadamente. Las siguientes dracmas (figs. 5-7), fueron acuñadas en algunas ciudades de Irán durante este período:

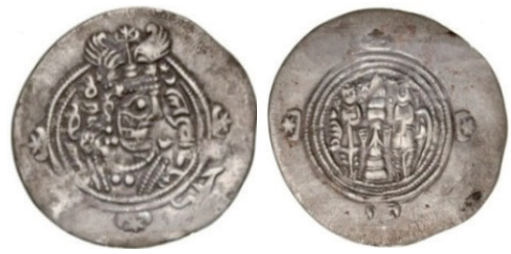

Fig. 5.

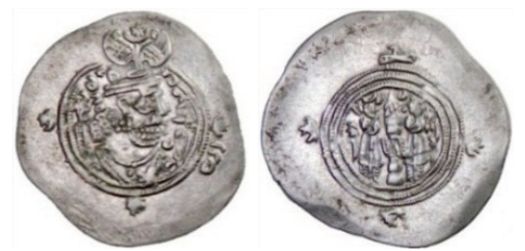

Fig. 6.

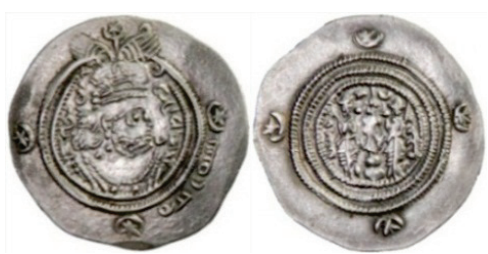

Fig. 7

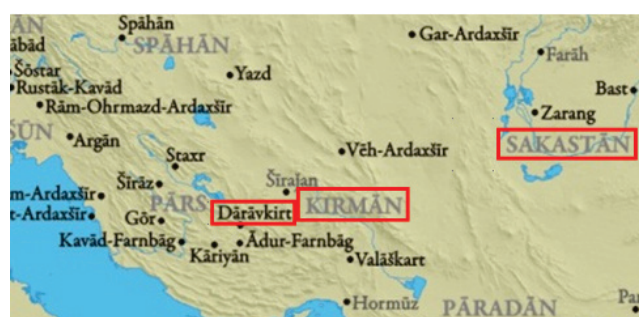

Fig. 5. Dracma árabe-sasánida del tipo Yazdgard III, acuñada en la provincia de Kirman (ceca incierta: BN, quizás Bamm). En el margen exterior del anverso se muestra la palabra tayyib (bueno). Fig. 6. Dracma árabe-sasánida del tipo Coroes II, acuñada en Darabjird (al Sudeste de Irán). En el margen exterior del anverso lleva la palabra "lillah" (para Allah). Fig. 7. Dracma árabe-sasánida del tipo tipo Yazdgard II acuñada en Sijistan, SK, (Sakastan) al Este de Irán. En el margen exterior muestra la leyenda: "bismi Allāh" (en el nombre de Allah).

${ }^{10}$ Sobre esta cuestión, ver: Alexander NIKITIN and Gunter ROTH, "The Earliest ArabSasanian Coins”, The Numismatic Chronicle, Vol. 155 (1995), pp. 131-137. 
En el año 35 H. / 656 d. C. Otmán fue asesinado, sucediéndole el yerno de Mahoma, Alí (35-40 H. / 656-661 d. C.). El por aquel entonces gobernador de Siria, Moawiya, viendo la pasividad de éste hacia el asesinato de Otmán, le consideró cómplice y se negó a reconocerle como nuevo jefe de la comunidad musulmana. Alí se instaló en Irak, estableciendo su cuartel general en la ciudad de Kufa, que había tomado partido por él desde el principio ${ }^{11}$. Nada más acceder al califato, los parientes de Otmán decidieron vengar su muerte. Moawiya, se enfrentó finalmente a los partidarios de Alí en la Batalla de Siffin del año 36 H. / 657 d. C., sobre la orilla derecha del Éufrates, donde fueron derrotados. Cuatro años después, Alí fue asesinado por un Jariyí, siendo elegido como nuevo califa el propio Moawiya. Durante su califato, Alí continuó emitiendo piezas de imitación bizantina y sasánida.

\section{LAS EMISIONES DE LOS CALIFAS OMEYAS}

La llegada de Moawiya I (41-60 H. / 661-680 d. C.) puso fin al periodo de los Califas Ortodoxos y dio paso al Califato Omeya, basado en un sistema puramente hereditario. En el Imperio Bizantino continuaba gobernando Constante II, tras cuya muerte, en el 668 d. C. / 49 H., sería sustituido por Constantino IV (668685 d. C. / 49-66 H.). Como capital del Califato, Mowiya eligió ahora la ciudad de Damasco, de la que había sido gobernador. Durante su califato se produjo, según Clive Foss ${ }^{12}$, el primer intento de organización dentro de las emisiones arábigas anteriores a la Reforma de Abd al-Malik. En Siria y Egipto se mantuvieron las series de bronces o feluses árabe-bizantinos, mientras que en Irán e Iraq se siguieron labrando dracmas sasánidas de imitación.

Sus primeras series de follis, consistentes de nuevo en "monedas derivativas", fueron de peso algo inferior a las emitidas hasta entonces, pero mantuvieron en su anverso las representaciones de emperadores bizantinos (solos o acompañados), y en el reverso la gran letra $\mathrm{M}$, con leyendas latinas o griegas alrededor. Sin

${ }^{11}$ La ciudad de KUFA continuaría siendo el feudo de Alí hasta su muerte en el 661 d. C. y desde el reinado de Moawiya se mantendrían allí también sus partidarios (conocidos como Chí́es), y una escisión de los musulmanes llamada Jariyíes. A diferencia de los Sunníes, que consideraban que el califa debía ser un árabe varón miembro de la tribu de Quraish, y de los Chiíes, quienes opinaban que debía ser Alí, yerno de Mahoma o un descendiente directo suyo, los Jariyies pensaban que el califa debía ser elegido por la comunidad.

${ }^{12}$ Clive FOSS, Arab-Byzantine Coins. An introduction, with a catalogue of the Dumbarton Oaks Collection, Washington, 2008, p. 39. 
embargo, a partir del año 50 H. / 670 d. C. debió ser cuando según Foss ${ }^{13}$ pudieron comenzar las denominadas "series bilingües", en las que aparecerá el nombre de la ciudad emisora en escritura griega, en arábiga, o en ambas. Con dicha medida parece que Moawiya pretendía ir reemplazando el heterogéneo grupo de bronces de imitación anteriores, por nuevas monedas con cierta organización.

Como dijimos, en Siria los territorios habían sido divididos por Omar en los cuatro grandes distritos militares: jund Damasco, jund Hims o Homs, jund AlUrdunn, y jund Filastin, existiendo además la posibilidad de que el propio Moawiya dividiese durante su califato el distrito de Homs, creando así el jund Quinnasrín $^{14}$, el más septentrional de todos ellos. En los cuatro primeros distritos o ajnad, fue donde se emitieron ahora las monedas árabe-bizantinas en 10 cecas diferentes, con un tipo de anverso propio y con la indicación de la ciudad emisora en su leyenda, bien en alfabeto griego, en alfabeto árabe, o en ambos (figs. 8-13):

Talleres emisores de feluses "bilingües"

- ANTARDUS / TARDUS. Tipo de Anverso: busto del Emperador. Leyendas: Anv.: (en árabe) بطردوس bi-tardus / Rev.: (en árabe) طيب "tayyib"= bueno.

- HIMS / HOMS. Tipo de Anverso: busto del Emperador. Leyendas: Rev.: (en griego) $\mathrm{C} / \mathrm{M} / \mathrm{I} / \mathrm{C} / \mathrm{H} / \mathrm{C}$.

- HELIOPOLIS / BAALBEK. Tipo de Anverso: dos figuras de pie. Leyendas: Rev.:

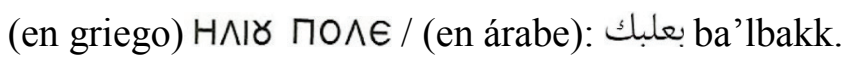

- DAMASCO. Tipo de Anverso: una figura de pie. Leyendas: Anv. o Rev.: (en grie-

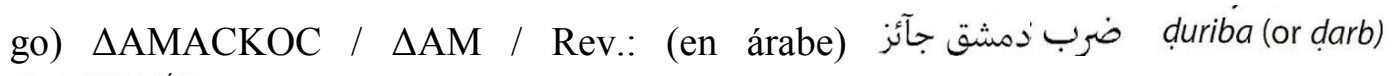
dimashq jä'iz.

- TIBERIADES / TABARIYA. Tipo de Anverso: tres figuras de pie. Leyendas: Rev,: (en griego y árabe -a la izquierda y en el exergo-THBEPIA $\triangle O$; a la derecha (en árabe) tabariya.

- BAYSAN / SCYTOPOLIS. Tipo de Anverso: dos figuras entronizadas. Leyendas: Anv.: (en griego) $\mathrm{CKY \Theta O} / \Pi \mathrm{O} \Lambda \mathrm{IC} / \mathrm{CKY \Theta -OPO} \Lambda \mathrm{HC}$.

- DIOSPOLIS / LUDD. Tipo de Anverso: una figura de pie. Leyendas: Anv.: (en griego) $\triangle \mathrm{IOC} \Pi \mathrm{O}$.

- JERUSALÉN / HIEROSOLIMA. Tipo de Anverso: una figura de pie. Leyendas: Anv.: (en griego) ICPOCO $\Lambda$ YNWN.

- GERASA. Tipo de Anverso: dos figuras de pie. Leyendas: Anv.: (en griego) TEPACON.

\footnotetext{
${ }^{13}$ Ibídem, p. 40.

${ }^{14}$ Ibídem, p. 39.
} 
- AMMAN. Tipo de Anverso: dos figuras, una sentada y la otra de pie. Leyendas: Rev.: (en árabe) هذا ضr hadhā duriba Ammān.

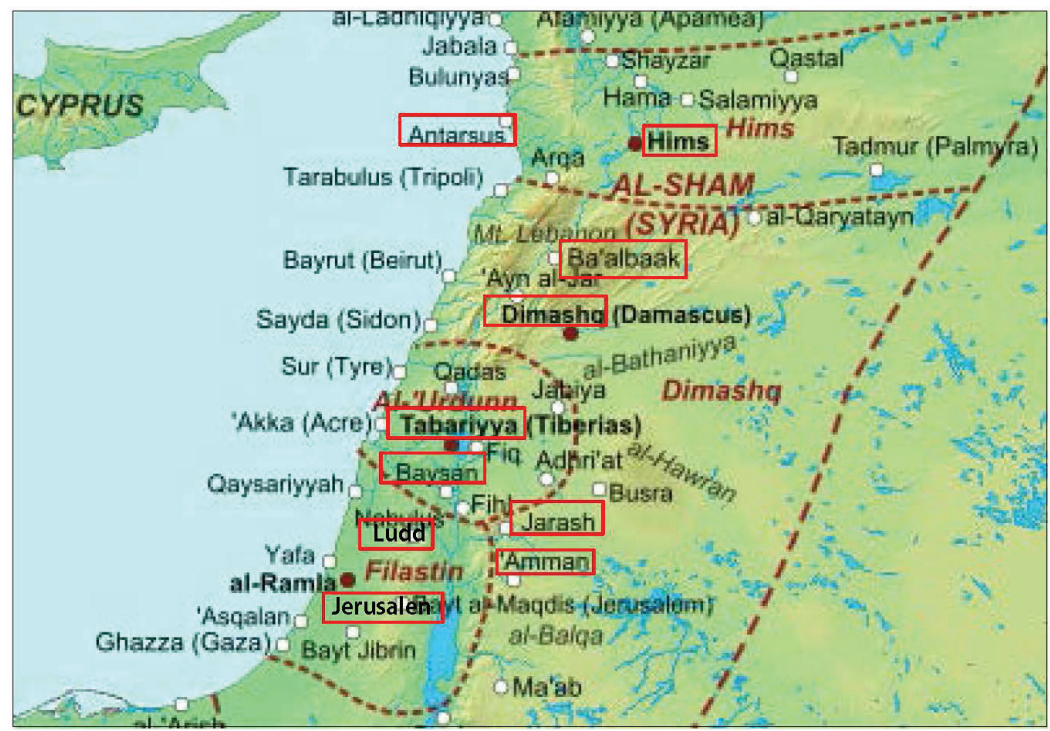

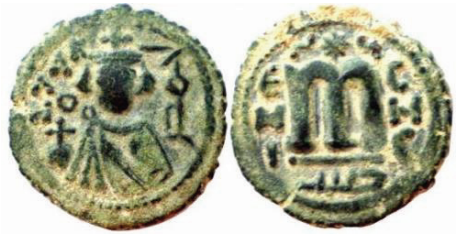

Fig. 8 .

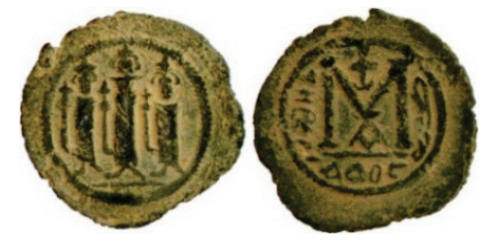

Fig. 10

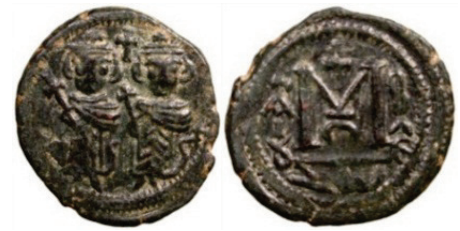

Fig. 12.

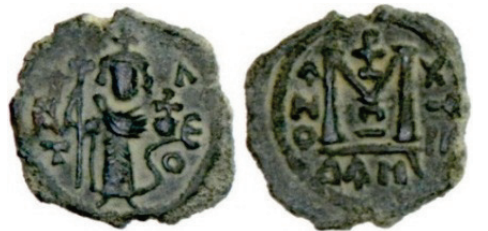

Fig. 9.

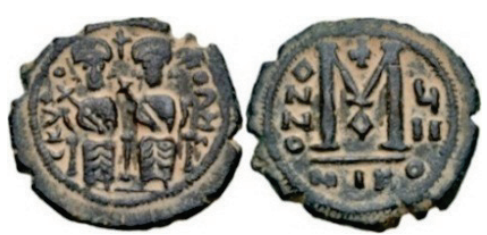

Fig. 11 .

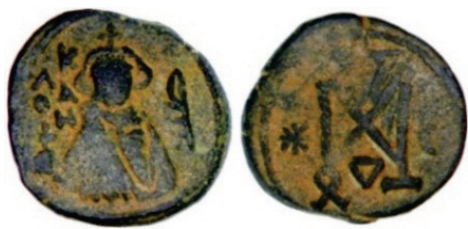

Fig. 13.

Fig. 8. Follis árabe-bizantino bilingüe. Hims (Emesa). Fig. 9. Follis árabe-bizantino bilingüe. Damasco. Fig. 10. Follis árabe-bizantino bilingüe. Tabariya. Fig. 11. Follis árabe-bizantino bilingüe. Baysan (Scythopolis). Fig. 12. Follis árabe-bizantino bilingüe. Baalbek (Heliopolis). Fig. 13. Follis árabe-bizantino bilingüe. Antardus (Tardus) ${ }^{15}$. Emitidos h. 50-60 H. / 670-680 d. C.

${ }^{15}$ Sobre las emisiones de Tardus o Tartus, véase: Wolfgang SCHULZE, "The ByzantineArab Transitional Coinage of Tartus", en The Numismatic Chronicle, N 173 (2013), pp. 245-260. 
Algunas de estas piezas (caso de Damasco y de Homs), mostraban en su reverso, junto al nombre de la ciudad emisora, las palabras "legal", o "bueno" (tayyib) (fig. 8), como inequívoco modo de atestiguar su validez, siendo además prueba del inicio de una organización y control de la moneda de bronce por parte de las autoridades centrales ${ }^{16}$.

En Irán e Irak se siguieron emitiendo dracmas árabe-sasánidas, con el busto del rey persa en el anverso y el altar de Zoroastro en el reverso, junto a reducidas leyendas arábigas en las orlas marginales del anverso. Sin embargo, algunas de ellas incorporaron ahora los nombres de diferentes gobernadores. Este fue el caso de Abd-Allah Ibn'Amir, conocido por su destreza como administrador y como militar, y que desempeñó el cargo de Gobernador de Basora (Irak) bajo el califa Otmán.

La provincia de Fars (en Irán), se había levantado junto con otras provincias, por lo que Otmán envió a Abd-Allah para aplastar las actividades de la rebelión. Tras conseguir la pacificación de los territorios rebeldes, Abd-Allah fue nombrado en el año 26 H. / 647 d. C. gobernador de Basora, permaneciendo en el cargo hasta que en el año 43 H. / 663 d. C. Moawiya le depuso debido, según se cree, a su creciente y peligrosa influencia en la ciudad.

Aunque Abd-Allah perdió la gobernación de Basora en dicho año, en la provincia de Fars se siguieron acuñando monedas a su nombre en diversas cecas hasta el año 46 H. / 666 d. C., es decir, durante al menos dos o tres años más, sin que se conozcan los motivos.

La figura 14 corresponde a una dracma de dicho gobernador acuñada en la ciudad de Bishapur (provincia de Fars). En el anverso se muestra el busto del rey persa a derecha, con la inscripción en Palhevi: "Haraman azfut" ("Su esplendor, su gloria, puede crecer") a la izquierda, y con el nombre del gobernador ( $A b d$ Allah Ibn 'Amir) a la derecha; en el margen exterior, en árabe lleva la leyenda: bismi Allāh ("En el nombre de Allah").

Otro de los gobernadores de quien se han conservado dracmas del mismo tipo, es de Ziyad ibn Abi Sufyan, (fig. 15) quien sucedió al propio Abd-Allah Ibn'Amir en la gobernación de Basora, y quien en el 50 H. / 670 d. C. fue nombrado también por Moawiya Gobernador de la ciudad Kufa.

\footnotetext{
${ }^{16}$ Clive FOSS, Arab-Byzantine Coins..., op. cit., p. 43.
} 


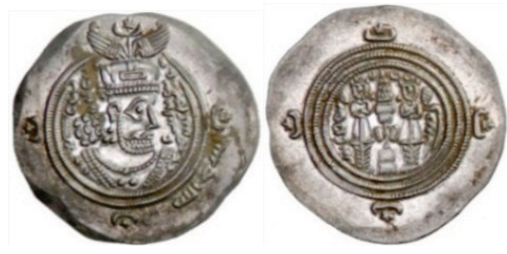

Fig. 14.

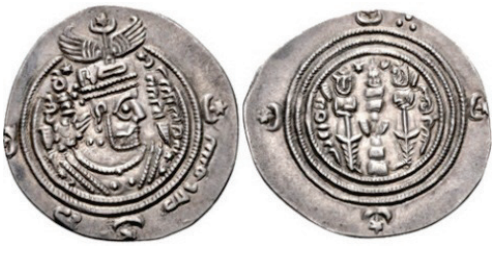

Fig. 15.

Fig. 14. Dracma árabe-sasánida de Abd Allah Ibn 'Amir, acuñada en Bishapur (BYSh) (Provincia de Fars). Fig. 15. Dracma árabe-sasánida de Ziyad ibn Abi Sufyan, como gobernador de Basora, emitida en la ceca de Sakastan en el $47 \mathrm{H}$. / 667 d. C. En el margen exterior y en árabe figura la inscripción: bismi Allāh rabbi ("en el nombre de Allah, mi Señor").

A finales del califato de Moawiya debieron comenzar las primeras emisiones arábigas de oro ${ }^{17}$, como consecuencia del tratado de paz al que Moawiya tuvo que llegar con el emperador Constantino IV, después de sucesivos enfrentamientos.

En el año 54 H. / 674 d. C. la flota árabe atacó Constantinopla por mar, sometiendo la ciudad a un prolongado y duro asedio, pero cuatro años después, en el 58 H. / 678 d. C. los bizantinos lograron rechazar el asedio árabe en la Batalla de Syllaeum tras emplear el denominado "fuego griego" 18 contra la flota árabe. En ese mismo año se produjo además la cuestión de los Mardaitas ${ }^{19}$. Según el testimonio del cronógrafo bizantino Teófanes recogido en su Crónica ${ }^{20}$, en dicho año los Mardaitas se apoderaron del Líbano, y tras unirse a ellos un gran número de esclavos huidos, prisioneros, y gente de todas clases, opusieron tal resistencia a los árabes, que obligaron a Moawiya a firmar un tratado de paz con el emperador

${ }^{17}$ Los principales investigadores en este tema han fijado de hecho el inicio de las series de oro hacia el año $60 \mathrm{H}$. / 680 d. C, es decir, en el mismo año de su muerte. Entre dichos autores destacan: G.C. MILES, "The Earliest Arab Gold Coinage", The American Numismatic Society Museum Notes, 1967, Volume 13, pp. 207-209; Stefan HEIDEMANN, "The Standing CaliphType - The Object on the Reverse", Coinage and History in the Seventh Century near East, 2, London, 2010, pp. 23-34, pp. 27-28, y Clive FOSS, Arab-Byzantine Coins..., op. cit., p. 41.

${ }^{18} \mathrm{El}$ "fuego griego" era un arma incendiaria utilizada por el Imperio bizantino. Creada en el siglo VI, se denominaba así, porque lanzaba un chorro de fluido ardiente. Podía emplearse tanto en tierra como en el mar, aunque preferiblemente en el mar.

${ }^{19}$ Los Mardaitas (término siríaco que significa "rebeldes") eran un grupo de cristianos, cuyos territorios, en la frontera arábigo-bizantina, se extendían desde los Montes Amanus (que separaban Cilicia de Siria), hasta la "ciudad sagrada" (Jerusalén). Formaban un muro de bronce, que protegía al Asia Menor de las invasiones árabes.

20 "En este año los Mardaitas invadieron el Líbano... dominando sus centros más importantes. Muchos esclavos, prisioneros y nativos huyeron hacia alli, de modo que en poco tiempo había muchos miles de ellos. Cuando Moawiya y sus asesores vieron ésto, decidió enviar embajadores a Constantino IV solicitándole la paz, e incluso prometiendo hacerle el pago de un tributo anual, consistente en 3.000 nomismata, cincuenta prisioneros y cincuenta caballos. (La versión que hemos utilizado en nuestro artículo, ha sido la siguiente: The Chronicle of Theophanes. Anni Mundi 6095-6305 (A. D. 602-813), Edited and Translated by Harry TURTLEDOVE, University of Pennsylvania Press, 1982, pp. 53-54). 
Constantino IV enormemente desfavorable para el primero, pero que aseguraba la paz durante treinta años. Los términos de esta tregua obligaron a los árabes a evacuar las islas que habían tomado en el mar Egeo y al pago de un tributo anual al emperador bizantino, consistente en cincuenta prisioneros, cincuenta caballos, y 3.000 nomismata. Por lo tanto, en mi opinión es posible que Moawiya ordenase acuñar hacia el año 60 H. / 680 d. C., esto es en el mismo año de su muerte, las primeras piezas de oro para el pago del tributo acordado, como más adelante haría también Abd al-Malik.

Se trataba de sólidus de imitación bizantina inspirados en los del ya fallecido Heraclio I, pero carentes de cualquier elemento o símbolo cristiano (Fig. 16). En su anverso mostraban el busto frontal del emperador bizantino y de su hijo Heraclio Constantino con dos sencillas coronas y rodeados de la leyenda latina ddNNhCЯCLI[...] (variante de: dd NN hERACLIUS ET hERA CONST PP AVG), y en el reverso una columna rematada por una pequeña barra horizontal, sobre tres escalones, rodeada de la inscripción: VICTORIA - AVÇY Z en latín también. El solidus de Heraclio I en el que se inspiró esta pieza era prácticamente similar; el anverso mostraba su busto coronado y el de su hijo, aunque con sus coronas rematadas en cruces y con otra cruz entre ambos, y en el reverso aparecía una cruz potenzada sobre escalones o gradas (Fig. 17). La columna con la barra horizontal del sólidus de Moawiya representaba al parecer el símbolo de la unidad de Allah, en contraposición con la cruz potenzada del sólidus de Heraclio, que era el símbolo de la Crucifixión de Cristo y de la Trinidad ${ }^{21}$.

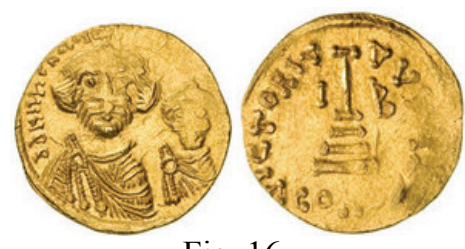

Fig. 16.

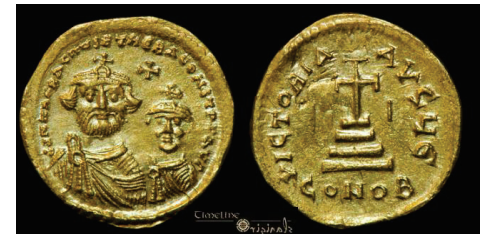

Fig. 17.

Fig. 16. Solidus árabe-bizantino imitando un Sólidus de Heraclio $I^{22}$, emitido posiblemente hacia el $60 \mathrm{H}$. / 680 d. C. Fig. 17. Solidus de Heraclio I con los bustos de Heraclio y de su hijo Heraclio Constantino $^{23}$.

${ }^{21} \mathrm{Al}$ parecer representaba la gran cruz que existía en la Iglesia del Santo Sepulcro de Jerusalén, en el lugar de la Crucifixión. En un interesantísimo trabajo, Stefan HEIDEMANN señaló cómo la cruz del reverso permitía además diferenciar los distintos valores de las monedas de oro bizantinas. El sólidus llevaba así una cruz potenzada sobre gradas, el semisis o mitad, una cruz potenzada sobre un globo, y el tremissis o tercio, una cruz potenzada rodeada de la propia leyenda (Stefan HEIDEMANN, "The Standing Caliph-Type-The Object on the Reverse...", op. cit., pp. 25 y 26).

${ }^{22} \mathrm{https}: / /$ www.numisbids.com/n.php?p=lot\&sid=461\&lot=7 [consultado el 17/03/2015].

${ }^{23} \mathrm{http} / / /$ wildwinds.com/coins/byz/heraclius/sb0739.jpg [consultado el 14/12/2014]. 


\section{EL PERIODO DE LAS GUERRAS CIVILES (60-73 H. / 680-692 d. C.)}

La muerte de Moawiya en el año 60 H. / 680 d. C. dio paso a un periodo de guerras civiles que se extendería a lo largo de algo más de una década. La idea de la sucesión hereditaria inaugurada por Moawiya, provocó tras su muerte un claro rechazo, por lo que durante este periodo los califas que gobernaron lo hicieron durante cortos periodos de duración. El primero de ellos, el hijo de Moawiya, Yazid I (60-64 H. / 680-683 d. C.), tuvo que enfrentarse a dos fuertes aspirantes al gobierno del estado islámico; en primer lugar al nieto del Profeta, Al-Husayn, y en segundo lugar a uno de los más influyentes miembros de la comunidad islámica por aquel entonces, Abd Allah ibn al-Zubayr.

Establecidos en Medina y después en la Meca, los dos rehusaron desde el principio a reconocer a Yazid I como nuevo califa. Yazid consiguió derrotar en el mismo año de su elección a Al-Husayn, pero al-Zubayr, beneficiado en gran medida por la insatisfacción generalizada entre la población con el gobierno omeya, envió un gobernador a Kufa y estableció su poder en un amplio territorio integrado por Irak, la región de Hiyaz (al sur de Arabia), y la mayor parte de Siria y de Egipto. Aunque Yazid I intentó poner fin a su rebelión invadiendo el Hiyaz, su repentina muerte en el 64 H. / 683 d. C. puso fin a la campaña. El imperio islámico quedó entonces divido en manos de dos califas diferentes. Uno de ellos fue el propio hijo de Yazid I, Moawiya II (64-64 H. / 683-684 d. C.), quien le sucedió en el mismo año de su muerte, pero a los cuatro meses abdicó en su primo segundo Marwan I (64-65 H. / 684-685 d. C.).

Convertido en el cuarto califa Omeya, Marwan I fue quien consiguió finalmente arrebatar a al-Zubayr el control sobre Egipto, Irak, Siria y parte de Arabia, quedando reducido básicamente su dominio desde entonces a la provincia del Hiyaz. Cuando en abril del año 65 H. / 685 d. C. Marwan I falleció, su hijo Abd al-Malik fue aceptado como nuevo califa en los territorios controlados por su padre, pero tampoco fue reconocido por al-Zubayr. Según el testimonio recogido por Teófanes $^{24}$, Abd al-Malik envió entonces emisarios al emperador Constantino IV, pidiendo las mismas condiciones de paz que habían sido solicitadas durante el reinado de Moawiya.

Las monedas emitidas durante los años de la guerra civil son difíciles de identificar, aunque no hay duda de que continuaron labrándose tanto bronces ára-

${ }^{24}$ The Chronicle of Theophanes..., op. cit. p.59. 
be-bizantinos como dracmas árabe-sasánidas, estas últimas a nombre de diferentes gobernadores.

El ejemplo ilustrado en la figura 18 es una dracma árabe-sasánida labrada a nombre de Ubayd Allah Ibn Ziyad. Ubayd Allah había sido nombrado gobernador de Kufa y Basora en el año 53 H. / 673 d. C., durante el califato de Moawiya I.

En el año 60 H. / 680 d. C. siendo todavía gobernador, el nuevo califa Yazid I le ordenó que acudiera a la ciudad de Kufa para mantener el orden, ante la popularidad que en ese momento había alcanzado allí el nieto del Profeta, Al-Husayn. Ubayd Allah marchó a Kufa y consiguió dar muerte a Al-Husayn en la Batalla de Karbala en octubre de ese mismo año.

Pero en el 63 H. / 683 d. C., tras la muerte de Yazid I, Ubayd Allah abdicó como gobernador de Kufa y Basora, refugiándose en Siria. Falleció en el año 65 H. / 685 d. C. en la batalla del río Khazir, cerca de Nínive.

La figura 19 es un follis árabe-bizantino de imitación dentro de las "monedas derivativas", perteneciente posiblemente y según Clive Foss ${ }^{25}$ a Yazid I (6064 H. / 680-683 d. C.) por la presencia de un posible halcón junto a la imagen del emperador $^{26}$.

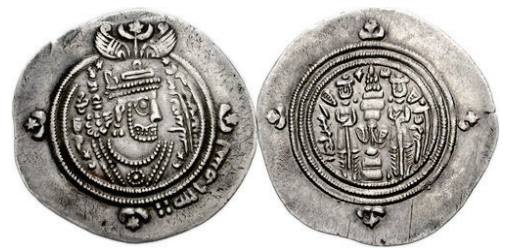

Fig. 18.

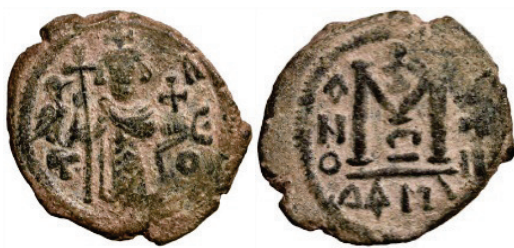

Fig. 19.

Fig. 18. Dracma árabe-sasánida de Ubayd Allah Ibn Ziyad, gobernador de Kufa. Emitido en Basora $^{27}$ (60 H. / 680 d. C.). Anverso: busto coronado de Cosroes II. A la izquierda: "Haraman Azfut" ("Su esplendor, su gloria, puede crecer") - y a la derecha: "Ubait Alla I ziyatan" (Ubayd Allah ibn Ziyad). En el margen exterior y en árabe: bismi Allāh ("en el nombre de Allah"). Reverso: altar del fuego flanqueado por dos asistentes. A la izquierda la marca de ceca (BCRA Basora), y a la derecha, la fecha. Fig. 19. Follis árabe-bizantino. Damasco ${ }^{28}, h .60 \mathrm{H}$. $/ 680 \mathrm{~d}$. C. Anverso: El emperador de pie y de frente, con lanza rematada en una cruz en una mano y con globo crucífero en la otra. A la izquierda pájaro ¿halcón? sobre una T; a la derecha: $\Lambda / \epsilon / O$. Reverso: gran letra M. A la izquierda: A /N /O; a la derecha: X/V/II; en el exergo: $\triangle A M$.

\footnotetext{
${ }^{25}$ Clive FOSS, Arab-Byzantine Coins... op. cit., pp. 47 y 57.

${ }^{26} \mathrm{Al}$ parecerel califa Yazid I era aficionado a la cetrería.

${ }^{27} \mathrm{http} / / /$ www.cngcoins.com/Coin.aspx?CoinID=119044 [consultado el 17/03/2015].

${ }^{28} \mathrm{http}: / / \mathrm{db}$. stevealbum.com/php/lot_auc.php? site=2\&sale=10\&lot=176\&lang=1 [consultado el 17/03/2015].
} 


\section{LAS EMISIONES DE ABD AL-MALIK HASTA LA APARICIÓN DE LA MONEDA "EPIGRÁFICA"}

En el año 65 H. / 685 d. C. Abd al-Malik ibn Marwan sucedió a su a padre Marwan I en plena guerra civil, teniendo que afrontar numerosas dificultades. Los habitantes de Arabia sólo reconocían como califa a Abd Allah ibn Al-Zubayr y los de Irak a Al-Mukhtar ${ }^{29}$, de manera que al principio Abd al-Malik sólo fue reconocido por los habitantes de Siria y de Egipto.

Con el Imperio Bizantino también tuvo problemas desde el comienzo. Abd al-Malik había subido al trono califal en el mismo año en que Justiniano II era proclamado emperador de Bizancio y desde el inicio de su gobierno, ambos estuvieron enfrentados. En el 67 H. / 686 d. C. Justiniano II envió tropas Mardaítas a asaltar la región de Siria, consiguiendo avanzar de nuevo hasta Líbano, lo que suponía una grave amenaza para el control árabe en la región. Abd al-Malik se vio obligado entonces a firmar un nuevo tratado con el emperador para mantener la paz. El emperador se comprometió a retirar las tropas Mardaítas fuera del Líbano y a detener sus ataques, mientras que Abd al-Malik se comprometió al pago de un nuevo tributo, que consistío — según el testimonio de Teófanes ${ }^{30}$ — en 1.000 nomismata, un caballo y un esclavo cada día. Finalmente en el tratado se acordó que Abd al-Malik pagaría a los bizantinos también la mitad de los ingresos procedentes de Chipre y Armenia, en compensación por reubicar el emperador a 12.000 Mardaítas en la costa sur de Asia Menor y en diversas partes de Grecia.

Es posible por tanto que en esos primeros años al frente del califato, Abd alMalik acuñase moneda de oro, para efectuar el pago del tributo y costear los numerosos enfrentamientos que en ese momento libraba. Su primera emisión, consistente de nuevo en Sólidus de imitación, pudo efectuarse hacia el 70 H. / 689 d. C. (fig. 20). En el anverso aparecían el emperador Heraclio I, y sus hijos Heraclonas y Heraclio Constantino, de pie y de frente, coronados y sujetando todos ellos un globo en su mano derecha. En el reverso, una columna sobre escalones, rematada por una pequeña barra horizontal, flanqueada por el monograma Pth - I, y rodeado de la inscripción latina: VICTORIA AVGY. El sólidus de Heraclio I en el que se inspiró esta otra pieza arábigo-bizantina, era prácticamente similar, aunque con elementos cristianos; en el anverso aparecían los mismos personajes co-

${ }^{29}$ Establecido en Kufa (Irak), Al-Mukhtar había encabezado una rebelión contra los Omeyas en venganza por la muerte de Al-Husayn en la Batalla de Karbala del año 680 d. C.

${ }^{30}$ The Chronicle of Theophanes..., op. cit. p. 61. 
ronados, con coronas rematadas en cruz y portando un globo crucífero, y en el reverso la cruz potenzada sobre escalones (fig. 21).

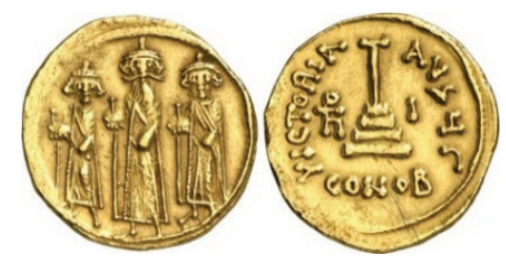

Fig. 20 .

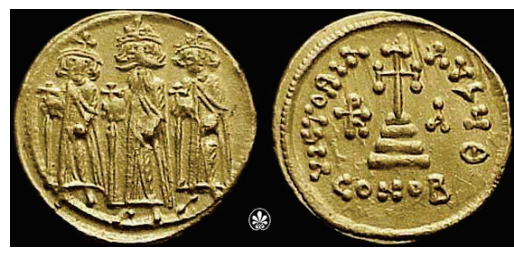

Fig. 21.

Fig. 20. Solidus árabe-bizantino imitando un sólidus de Heraclio I emitido h. el $70 \mathrm{H}$. / 689 d. C. ${ }^{31}$. Fig. 21. Solidus de Heraclio I con los bustos de Heraclio I, Heraclonas y Heraclio Constantino ${ }^{32}$.

Durante los primeros años de gobierno de Abd al-Malik, se siguieron acuñando en los diversos territorios del mundo árabe monedas de bronce de tipo árabe-bizantino, así como dracmas árabe-sasánidas a nombre de diferentes gobernadores. La figura 22 corresponde a una dracma árabe-sasánida emitida en la provincia de Fars (Irán), en el mismo año de la accesión de Abd al-Malik al califato $\left(65\right.$ H. / 685 d. C.), por el gobernador Zubairí ${ }^{33}$ de Bishapur Abd al-Malik ibn `Abd Allah, mientras desempeñó su cargo. Su dracma, con la tipología habitual, incorporaba por primera vez el nombre de Mahoma, al incluir en la leyenda exterior del anverso, y tras la leyenda de invocación, el inicio de la Misión Profética de Mahoma: "Bismi Allāh - Muhammad rasūl Allāh ("En el nombre de Allah, Mahoma es el enviado de Allah"). Sus emisiones de dracmas se prolongaron durante cuatro años más.

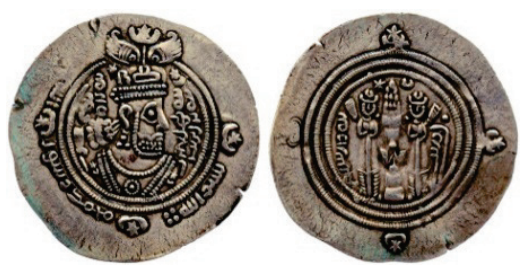

Fig. 22.

Fig. 22. Dracma árabe-sasánida del gobernador de Bishapur, Abd al-Malik ibn`Abd Allah. Emitida en el año $65 \mathrm{H} . / 685$ d. C. ${ }^{34}$. Anverso: busto coronado de Cosroes II. A la izquierda: "HARAMAN AZFUT" ("Su esplendor, su gloria, puede crecer") - y a la derecha: "ABD AL-MALIK IBN 'ABD $A L L \bar{A} H$ ". En el margen exterior y en árabe: Bismi Allāh Muhammad rasūl Allāh ("En el nombre de Allah, Mahoma es el enviado de Allah"). Reverso: altar del fuego flanqueado por dos asistentes. A la izquierda la marca de ceca (BYŠh - Bishapur), y a la derecha la fecha.

\footnotetext{
${ }^{31} \mathrm{https}: / /$ www.numisbids.com/n.php?p=lot\&sid=915\&lot=226 [consultado el 18/05/2015].

${ }^{32} \mathrm{http} / /$ www.wildwinds.com/coins/byz/heraclius/sb0764.jpg [consultado el 21/01/2015].

${ }^{33}$ Es decir, partidario de Al- Zubayr.

${ }^{34}$ https://www.numisbids.com/n.php?p=sale\&sid=826 [consultado el 18/02/2015].
} 
En el año 72 H. / 691 d. C. Abd al-Malik emitió también y por primera vez en Siria (en Damasco y Homs) dracmas del tipo árabe-sasánida. Las emisiones de plata se habían producido hasta entonces sólo en los territorios orientales de Irán e Irak, pero ni Damasco ni el resto de las ciudades de Siria tenían tradición en la acuñación de esta moneda; de manera que es posible que Abd al-Malik tomara esta decisión, con la intención de familiarizar a la población de allí con dicho numerario, y de extender su circuito comercial así. Las dracmas mantenían la tipología habitual, con el busto de Cosroes II en el anverso y el altar flanqueado por dos asistentes en el reverso, pero en función de sus leyendas, mostraban dos variantes.

El primer tipo (fig. 23) llevaba a la izquierda del busto del rey su nombre en palhevi y a la derecha la inscripción árabe: Muhammad / rasūl Allāh, y en el margen externo: Bismi Allāh. En el reverso, a los lados del altar, se recogían en árabe tanto la fecha como la ceca: ithnayn wa saba in (año 72 H.) - Dimashq. El segundo tipo (fig. 24) (emitido también en Homs ${ }^{35}$ ), mantenía el nombre del rey persa en palhevi a ambos lados de su busto, y en el margen exterior mostraba la leyenda más larga: Bismi Allāh - Muhammad - rasūl Allāh.

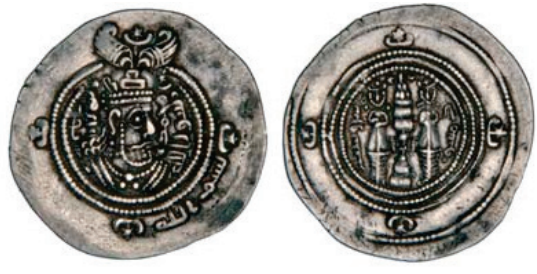

Fig. 23.

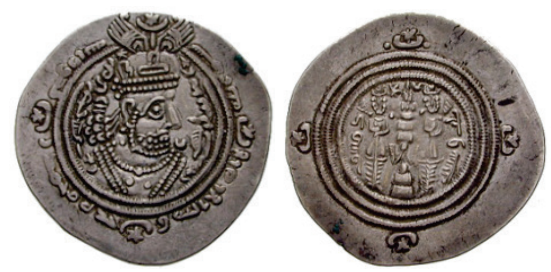

Fig. 24.

Fig. 23. Dracma árabe-sasánida. Damasco, emitida en el año 72 H. / 691 d. C. Fig. 24 ${ }^{36}$. Dracma árabe-sasánida. Damasco, emitida en el año 72 H. $/ 691$ d. C.).

En el mismo año 72 H. / 691 d. C. o quizá un poco antes, parece ser que Abd al-Malik efectuó una nueva emisión de oro. Teófanes en su Crónica relata de hecho, cómo en dicho año Abd al-Malik envió a Justiniano II monedas de oro "de un nuevo tipo nunca hecho hasta entonces" para el pago de su tributo, que el emperador se negó a aceptar, rompiendo además la paz con Abd al-Malik ${ }^{37}$. Aunque los diseños de las nuevas piezas, denominadas probablemente ahora Dinares, recordaban a los de los sólidus de imitación anteriores, éstos mostraban diferencias, dado que el califa decidió "islamizar" ahora sus monedas. Aunque su anverso

\footnotetext{
${ }^{35}$ Clive FOSS, Arab-Byzantine Coins... op. cit., p. 66.

$36 \mathrm{http} / /$ www.islamic-awareness.org/History/Islam/Coins/drachm19.html [consultado el 17/03/2015].

${ }^{37}$ The Chronicle of Theophanes...,op. cit. p.63 (Este suceso es mencionado también en: Luke TREADWELL, "Abd al-Malik's Coinage Reforms: the Role of Damascus", in Revue numismatique, vol. 165 (2009), pp. 357-381, p. 365).
} 
mostraba de nuevo a tres personajes de pie y de frente, parece que éstos no representaban ya al emperador y a los miembros de su familia, sino al Profeta Mahoma, acompañado de su compañero y quien se convertiría en el primer califa Abu-Bakr (a la izquierda), y de su esposa Aisha (a la derecha), sujetando todos ellos una espada en su mano derecha. En el reverso se mantenía la columna sobre escalones, pero rematada ahora en un globo (fig. 25).

La leyenda, escrita íntegramente en árabe, figuraba sólo en el reverso e introducía, tras la fórmula de invocación, el comienzo de la Profesión de fe musulmana y el inicio de la Misión Profética de Mahoma. Decía: Bismi Allāh, la ilaha illa Allāh, wahdahu, Muhammad rasūl Allāh ("En el nombre de Allah. No hay dios sino Allah, sólo él, Mahoma es el enviado de Allah"). Aunque no figuraba el nombre de la ceca, se cree que las piezas se acunaron en Damasco, y durante muy pocos años. El rechazo del emperador hacía estas nuevas piezas, reabrió entonces las hostilidades entre musulmanes y bizantinos.

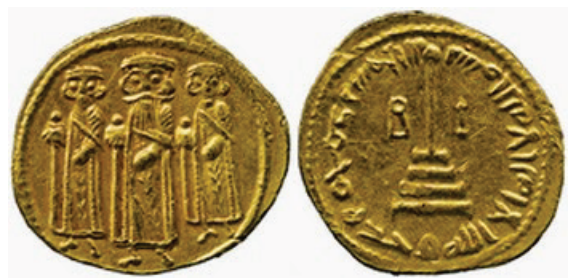

Fig. 25.

Fig. 25. Dinar de Abd al-Malik (h. 72-73 H. / 691-692 d. C.). Damasco.

\subsection{La unificación del Islam y el inicio de las acuñaciones del "Califa de pie" (73 H. / 692 d. C.)}

En el año 73 H. / 692 d. C. Abd al-Malik consiguió la unidad del Mundo Islámico, cuando su general Al-Hajjaj ibn Yusuf derrotó y dio muerte a su gran rival Abd-Allah ibn Al-Zubayr. Tras lograr la unificación política, el califa efectuó una primera reforma monetaria desarrollando una producción a gran escala en los tres metales, especialmente en bronce, e introduciendo en buena parte de las monedas su propia imagen. Como puntualizaban Ingrid y Wolfang Schulze ${ }^{38}$, esta primera reforma se desarrolló de un modo gradual, debiendo ser controlada además por los gobernadores de los distintos ajnād. Durante este periodo se efectuaron numerosos ensayos y diseños "experimentales" en los que se intentaban ofre-

${ }^{38}$ Ingrid and Wolfang SCHULZE, "The Standing Caliph Coins of al-Jazīra: some problems and suggestions", en The Numismatic Chronicle, 170 (2010), pp. 331-352, p. 335. 
cer imágenes alusivas al nuevo régimen islámico, y de hecho muchos autores denominan a esta primera etapa, como la de las "emisiones experimentales". Dichas emisiones se desarrollaron desde el 74 H. / 693 d. C., hasta la aparición de la moneda "anicónica", fruto de su segunda y definitiva reforma monetaria aplicada a partir del año 77 H. / 696 d. C.

En el año 74 H. / 693 d. C. Abd al-Malik emitió un nuevo dinar con enorme contenido religioso pero político también, al figurar su imagen en el anverso. $\mathrm{Su}$ emisión parece que tuvo mucho que ver con el nuevo tipo de sólidus que Justiniano II acababa de poner en circulación. Desde el comienzo de su reinado el emperador había acuñado sólidus con la tipología tradicional, consistente en su busto coronado en el anverso, y la cruz potenzada sobre escalones en el reverso. Sin embargo en el año 692 d. C. acuñó un nuevo tipo de sólidus cargado de enorme simbolismo cristiano (fig. 26).

$\mathrm{Su}$ anverso fue ocupado ahora por la imagen de Cristo bendiciendo con una mano y con el libro de los Evangelios en la otra, rodeado de la leyenda: IHS CRIST D S REX REGINORVM "Ihesus Cristus Dominus Salvator Rex Regnorum" (Jesucristo, Señor Salvador, Rey sobre los que gobiernan). En el reverso era donde se mostraba ahora a Justiniano II de pie, coronado, con loros, sujetando con su mano derecha la cruz potenzada sobre escalones, y con la leyenda: D IUSTINIANU-S SERV ChRISTI alrededor. Como se verá más adelante, la leyenda del anverso: (“Jesucristo..., Rey sobre los que gobiernan”), se cree que fue colocada como un claro ataque al nombre del propio Abd al-Malik, el cual significaba literalmente en árabe "El sirviente del Rey".

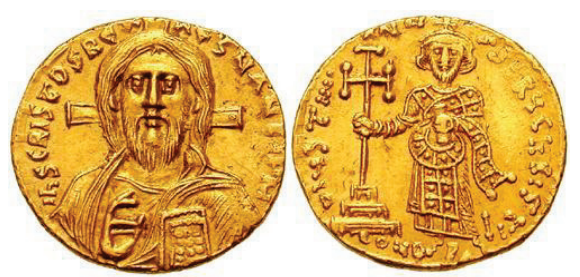

Fig. 26.

Fig. 26. Solidus de Justiniano II. Constantinopla (acuñado entre 692 y 695 d. C.) ${ }^{39}$.

El importante cambio iconográfico del nuevo sólidus de Justiniano II, parece que fue originado por una de las decisiones tomadas durante el segundo Sínodo Trulliano $^{40}$, convocado por el emperador en el año 73 H. / 692 d. C. Entre los di-

\footnotetext{
${ }^{39} \mathrm{http}: / /$ www.wildwinds.com/coins/byz/justinian_II/sb1249.jpg [consultado el 23/12/2014].

${ }^{40}$ El término Trullano alude a la sala cupulada del Palacio imperial de Constantinopla en donde se celebraron las sesiones, conocida con el nombre de trullos (cúpula). Dicho Sínodo fue convocado por Justiniano II en el año 692 d. C. para completar las decisiones dogmáticas de los dos Concilios
} 
versos puntos tratados en sus numerosas sesiones, se debatió la cuestión de cómo debía representarse a Cristo. En la sentencia o Canon 82 (de los 102 que se emitieron), se decretó que en adelante debería mostrársele en forma humana, y no mediante representaciones simbólicas, tales como la del Cordero de Dios, u otras que habían prevalecido durante el periodo anterior del cristianismo ${ }^{41}$. Aunque tras el Sínodo surgieron numerosas disputas entre los partidarios de la utilización de las imágenes religiosas y los que se oponían a ellas (iconoclastas), se cree que la introducción del retrato de Cristo en las monedas de Justiniano II pudo haber sido el resultado de dicho decreto.

Además de la disputa ideológica, la aparición de la imagen de Cristo en sus monedas suscitó el rechazo inmediato del Califa Abd al-Malik, quien decidió emitir por tanto en el año 74 H. / 693 d. C. un nuevo Dinar mucho más islamizado (fig. 27). El anverso mostraba ahora su figura de pie y de frente con vestimenta árabe, agarrando su espada envainada, y rodeado de la leyenda arábiga con el comienzo de la Profesión de fe y el de la Misión Profética de Mahoma: "No hay dios sino Allah sólo él, Mahoma es el enviado de Allah".

El reverso mantenía la columna sobre escalones, rematada en un globo, y rodeado de la leyenda "En el nombre de Allah", además de diversos datos referentes a la moneda: "este Dinar fue acuñado en el año cuatro y setenta". La columna rematada por un globo, continuaba siendo el símbolo del principio básico del Islam: la unidad de dios o de Allah, frente a los tres brazos de la cruz, que representaban la Santísima Trinidad y la cruz de la Crucifixión. En cuanto a la figura del califa, con su mano en la empuñadura de la espada y en actitud de desenfundarla y no con la espada en alto, se trataba de una representación un tanto amenazante y opuesta a la de Cristo bendiciendo, en actitud completamente pacífica.

Estos dinares fueron acuñados en la ceca de Damasco entre el 74 H. / 693 d. C. y el 77 H. / 696 d. C., es decir, durante unos pocos años. Según Lucke Treadwell $^{42}$, el hecho de que se emitieran en pequeñas cantidades y durante tan poco tiempo, evidencia que su objetivo no fue realmente el de reemplazar al sólidus bizantino de la circulación en sus territorios, sino probablemente el de extender la nueva imagen del nuevo régimen islámico.

ecuménicos anteriores, el Quinto (del año 553 d. C.) y el Sexto (del 680/681); por eso se le conoce también a este Sínodo como el Concilio Quintisextum.

${ }^{41}$ Sobre esta cuestión véase: http://www.cngcoins.com/Article.aspx?ArticleID=136, [consultado el 23/05/2015].

${ }^{42}$ Luke TREADWELL, “Abd al-Malik's Coinage Reforms...”, op. cit., p.370. 


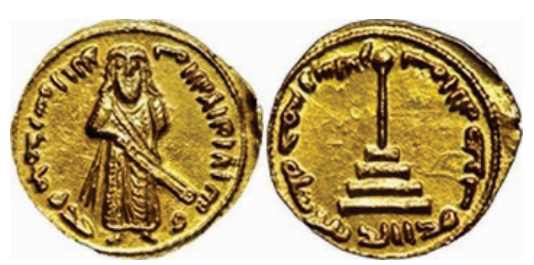

Fig. 27.

Fig. 27. Dinar de Abd al-Malik. Emitido en Damasco y fechado en el 76 H. / 695 d. C.

En Irak, el hermano de Abd al-Malik y por aquel entonces gobernador de Kufa, Bishr ibn Marwan ${ }^{43}$, efectuó por su parte en el año 73 H. / 692 d. C. una emisión de dracmas árabe-sasánidas en aquella ciudad, en la que por primera vez se rompía con la iconografía tradicional del reverso de estas piezas (fig. 28). En su anverso aparecía todavía el busto del rey Cosroes II, entre la leyenda en palhevi: Haraman Azfut, "Su esplendor, su gloria, puede crecer" (a la izquierda) - y Bsyr y Mrwanan "Bishr ibn Marwan" (a la derecha), y en el margen exterior y en árabe: Bismi Allāh Muhammad rasūl Allāh ("En el nombre de Allah, Mahoma es el enviado de Allah").

Sin embargo en su reverso, en lugar del tradicional altar flanqueado por dos asistentes, se mostraban ahora tres figuras de pie y de frente. La central, flanqueada por dos asistentes, tenía las manos extendidas como un orante. Este personaje, identificado con Abd al-Malik, o con el propio Bishr ibn Marwan, parece estar pronunciando la $k h u t b a^{44}$ de los viernes con ambas manos alzadas. Se trata de una imagen de enorme contenido religioso y que parece representar a la figura central o protagonista, como el Jatib o la persona que recita el sermón durante la oración de los viernes. Por ello parece más lógico que pudiera tratarse de una alusión iconográfica al liderazgo espiritual del califa-imán, y por lo tanto una representación del propio Abd al-Malik, no de su hermano. En el campo, a la izquierda y en palhevi, se mostraba la fecha y a la derecha, en palhevi también, el nombre de la ceca $\left(A k w l a=a l-K u f a^{45}\right)$.

Este tipo de dracmas, conocidas por su imagen del reverso como las dracmas del "Califa orante", se siguieron emitiendo hasta el 75 H. / 694 d. C.) en Kufa, así como en Basora.

43 En el año 71 H. / 690 d. C. Abd al-Malik ibn Marwan, nombró a su hermano Bishr gobernador de Kufa, y dos años después, en el 73 H. / 692 d. C. le nombró gobernador de Basora.

${ }^{44}$ La khutba o Jutba es el sermón pronunciado por el Jatib durante la oración de los viernes.

${ }^{45} A K W L A$ era el nombre originario de la ciudad del sur de Irak que los árabes refundaron bajo el nombre de Kufa. 


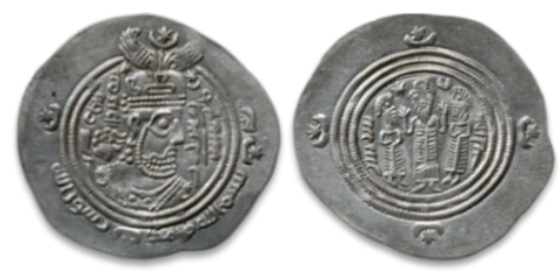

Fig. 28.

Fig. 28. Dracma árabe-sasánida del "Califa orante", emitida por el hermano de Abd al-Malik, Bishr ibn Marwan en Kufa. 73 H. / 692 d. C. ${ }^{46}$.

En el 75 H. / 696 d. C., a los dos años de comenzar esta emisión de dracmas “experimentales" en Irak, el propio Abd al-Malik efectuó otras dos en Damasco. La primera de ellas, conocida normalmente como la "dracma del Califa" (fig. 29), mantenía en el anverso el busto de Cosroes II a derecha con el característico tocado de alas anchas, flanqueado por la leyenda en árabe:"duriba fi /sanat" "khamsa wa sab ìn" ("acuñado en el año 75"), mientras que en el margen externo mostraba la leyenda: "Bismi Allāh / lā-ilaha il-Allāh / waḥdahu Muhammad ra / sūl Allāh" ("En el nombre de Allah, no hay dios sino Allah sólo él, Mahoma es el enviado de Allah"). Pero en el reverso y como novedad, se mostraba su figura de pie y de frente, apoyando su mano derecha en una espada envainada, y flanqueado por las leyendas arábigas: "khalfat (sic) Allāh / amīr al-mu'minīn" ("Califa de Allah, / Príncipe de los creyentes"). Aunque no figuraba expresamente su nombre en la leyenda, la identificación del personaje con Abd al-Malik no ofrece dudas, dado que lo que sí aparecen son los títulos que detentó en vida: "Califa de Allah" y "Príncipe de los creyentes".

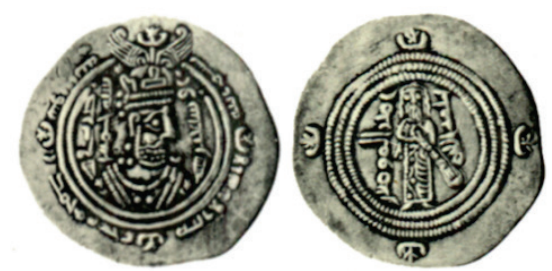

Fig. 29.

Fig. 29. Dracma árabe-sasánida "del Califa" (1 ${ }^{a}$ serie) 75 H. / 694 d. C., Emitida probablemente en Damasco por Abd al-Malik ${ }^{47}$.

La segunda serie tenía un anverso en apariencia similar al anterior, aunque un poco más evolucionado y un reverso completamente distinto (fig. 30). Conocida como la "dracma del Mirhāâ", su anverso mostraba el clásico busto real de

$46 \mathrm{http}: / / \mathrm{www} . d a v i d m u s . d k /$ en/collections/islamic/dynasties/umayyads/coins/c369?print=1 [consultado el 17/03/2015].

$47 \mathrm{http} / /$ www.islamic-awareness.org/History/Islam/Coins/drachm24.html [consultado el $23 / 12 / 2014]$. 
perfil pero claramente modificado respecto a la versión del prototipo sasánida. El tocado, mucho más sencillo, no llevaba ahora las alas anchas, y en su mano derecha aparecía colgada una espada envainada: la leyenda (todavía en palhevi) era la tradicional de las dracmas sasánidas: Haraman Azfut (a la izquierda) - Khusraw (a la derecha).

La leyenda exterior decía: "Bismi Allāh / lā-ilaha il-Allāh / waḥdahu Muhammad ra / sūl Allāh" ("En el nombre de Allah, no hay dios sino Allah sólo él, Mahoma es el enviado de Allah"). El reverso mostraba un arco apoyado sobre dos columnas (supuestamente un Mirhāa), cobijando una lanza (la'Anaza), y flanqueado por dos inscripciones en árabe: amīr al-mu'minīn (a la izquierda) y khalfat Allāh (a la derecha). A ambos lados de la lanza figuraban también las inscripciones: nasr - Allah (La Victoria de Allah) ${ }^{48}$.

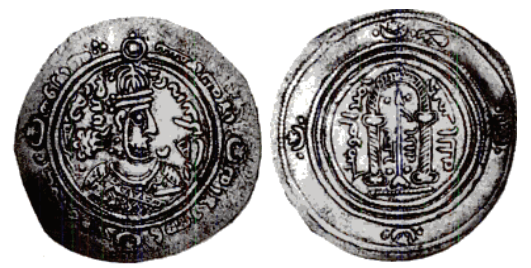

Fig. 30.

Fig. 30. Dracma árabe-sasánida "del Mihrab" (2 ${ }^{a}$ serie), 75 H. $/ 694$ d. C. Emitida probablemente en Damasco por Abd al-Malik.

Otra de las emisiones de dracmas experimentales de esta época fue la efectuada por el gobernador de Irak, Al-Hajjaj ibn Yusuf.

Como recompensa por haberle ayudado a derrotar a Al-Zubayr, en el 75 H. / 694 d. C. Abd al-Malik le concedió la gobernación de Irak, desde donde se dispuso a organizar las provincias orientales del califato, convirtiéndose también en gobernador de varias provincias de Persia. Pues bien, durante los dos años siguientes la ceca de Bishapur (Irán) emitió dracmas árabe-sasánidas a su nombre con otro curioso diseño experimental (fig. 31).

Su anverso mantenía el busto de Cosroes II, pero acompañado del nombre del gobernador (“al-Hajjāj bin Yūsuf”), y alrededor de éste y en una curiosa disposición radial compuesta por grupos de letras, figuraba la leyenda: Bismi Allāh lā-ilaha il-Allāh waḥdahu Muḥammad rasūl Allāh ("En el nombre de Allah, no hay dios sino Allah sólo él, Mahoma es el enviado de Allah"). El reverso mante-

${ }^{48}$ Sobre esta emisión, véase: Luke TREADWELL, “«Mihrab and 'Anaza» or «Sacrum and Spear»? A Reconsideration of an Early Marwanid Silver Drachm”. In Muqarnas: An Annual on the Visual Culture of the Islamic World, XXII, (2005), pp. 1. 
nía la tipología tradicional, con el altar flanqueado por los dos asistentes y con el nombre de la ceca (en este caso: Bishapur).

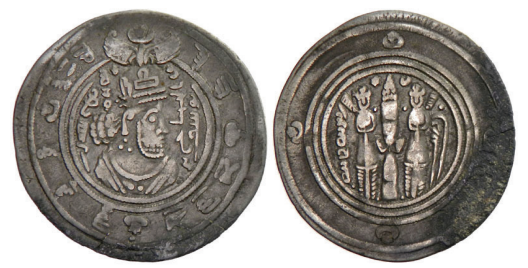

Fig. 31.

Fig. 31. Dracma árabe-sasánida radial de Al-Hajjaj ibn Yusuf. Bishapur. 77 H. / 696 d. C.

Hacia el año 74 H. / 693 d. C., y dentro de su primera reforma monetaria dirigida hacia la centralización de la administración del estado islámico, Abd alMalik inauguró también una gran emisión de bronce denominada del "califa de pie", dado que ese será el motivo que aparecerá siempre en el anverso de las piezas. Se trata de unas emisiones regulares que se desarrollaron entre el 74 H. / 693 d. C. y el 77 H. / 696 d. C. en Siria, siendo además las últimas que mostraron en las monedas de dicho territorio representaciones humanas.

La mayoría de los centros emisores de los nuevos feluses - casi una veintena- se localizaron, como observó Luke Treadwell ${ }^{49}$, al norte de los territorios de Siria, especialmente en el jund Quinnasrin, que hasta entonces no había emitido moneda de bronce, pero donde ahora se abrieron numerosos talleres. Por el contrario las cecas del sur, emplazadas en los distritos o ajnād de Filastin o de AlUrdunn, serán escasas. Las cecas ubicadas en el norte pudieron abrirse de este modo, según Ingrid y Wolfang Schulze ${ }^{50}$, para pagar a las tropas que aseguraban las fronteras en el norte de Siria, siendo por tanto utilizadas en aquellas ciudades donde se habían establecido los soldados.

Talleres emisores de feluses del "califa de pie"

JUND AL-JAZIRA: Al-Ruha y Harran,

JUND QUINNASRIN: Qinnasrīn, Halab (Aleppo), Qūrus, Jibrīn, Sarmīn, Ma'arrat Misrīn y Manbij.

JUND HIMS: Emesa (Homs).

JUND DIMASHQ: Heliopolis (Baalbek), Damasco (Dimasq), y 'Ammān.

JUND AL-URDUNN: Tabariya (Tiberias).

JUND FILASTIN: Hierosolyma (Iliya), Diospolis (Ludd) y Yubnā.

\footnotetext{
${ }^{49}$ Luke TREADWELL, “Abd al-Malik's Coinage Reforms...”, op. cit., p.370.

${ }^{50}$ Ingrid and Wolfang SCHULZE, "The Standing Caliph Coins of al-Jazīra...”, op. cit., p. 332.
} 


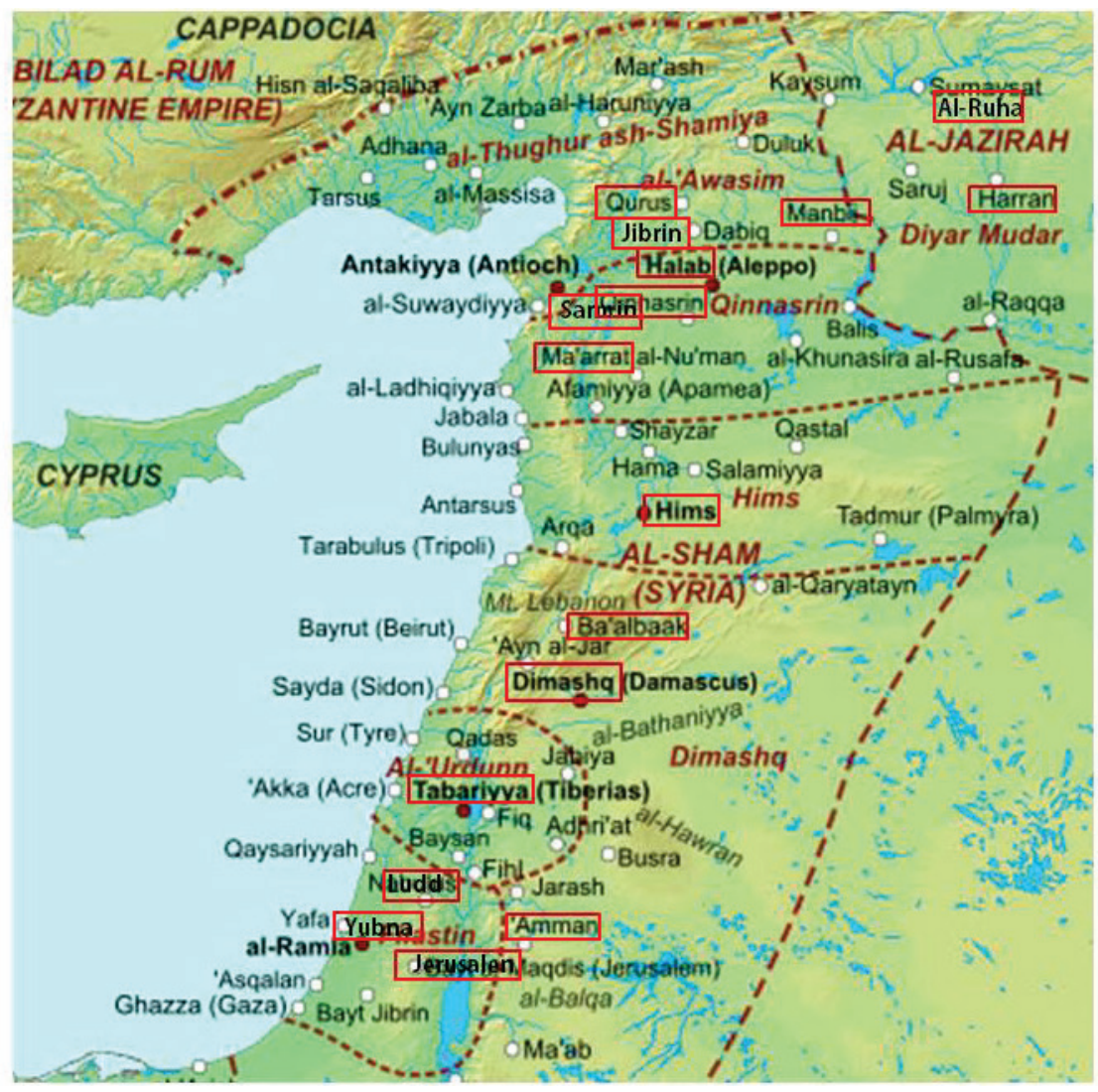

Como señaló Clive Foss ${ }^{51}$, estas abundantes series de feluses se pueden agrupar en dos grandes categorías, en función de los tipos que poseen.

- La primera de ellas corresponde a la mayor parte de las piezas, las cuales fueron acuñadas en 11 cecas repartidas entre los distritos o ajnād de Quinnasrin, Homs, Damasco, Al-Urdunn y Al-Jazira. En su anverso llevan la imagen del califa Abd al-Malik de pie y de frente, con vestimenta árabe y sujetando una espada envainada en diagonal, y con la leyenda arábiga alrededor. En el reverso muestran un poste sobre escalones atravesado por lo que parece ser la letra griega: $\Phi$, rematado normalmente por un globo o en alguna ocasión por una flecha. En cuanto a sus leyendas, existen variaciones entre las monedas labradas en los distintos talleres, pero la escritura empleada ahora es siempre el árabe.

- La segunda categoría o grupo, corresponde a las monedas pertenecientes al jund Filastin (Palestina). Las cecas de este otro distrito incorporaron en el anverso también la imagen del califa de pie, pero en el reverso mantuvieron la letra m (marca de valor del follis bizantino).

${ }^{51}$ Clive FOSS, Arab-Byzantine Coins..., op. cit., p. 67. 
El significado del curioso símbolo del reverso de las monedas del primer grupo, ha sido enormemente debatido en las últimas décadas. Durante mucho tiempo se consideró una simple modificación de la cruz sobre gradas derivada de los prototipos bizantinos, pero en los últimos años han surgido diversas interpretaciones. Autores como J. Walker ${ }^{52}$ opinaban que la supuesta letra $\Phi$ del símbolo, podría ser la phi de follis y por tanto la propia marca de valor de la moneda, del mismo modo que los tremissis en el Norte de África mostraban en su reverso un poste o columna sobre gradas rematada en forma de $\mathrm{T}$ como marca de valor ${ }^{53}$.

A pesar de ello, las más recientes teorías identifican el poste atravesado por $\Phi$, con la $Q U T B^{54}$, un término árabe para el que no existe una definición clara, pero que significa algo así como el Polo de los Polos, el Polo del Ser (el Hombre Perfecto) y que en la moneda simbolizaría al califa como centro de la comunidad islámica.

En palabras de Wolfang Schulze ${ }^{55}$, el símbolo sobre escalones de las monedas de bronce no fue ninguna adaptación de la cruz sobre escalones bizantina, sino un intento de crear un símbolo religioso propio para el Islam, en un momento en el que el gobierno árabe en Siria se estaba desarrollado como una teocracia.

La homogeneización tipológica de las series de bronce, no tuvo por el contrario su reflejo en las leyendas monetales, produciéndose grandes variaciones en las de las monedas emitidas en los diferentes ajnad o distritos.

En el jund Qinnasrīn (figs. 32-35), los feluses siempre llevan en el reverso la palabra wäfin (valor verdadero) junto al nombre de la ceca, con la única excepción Sarmīn. Los de Manbij, Ma'arrat Misrin y Sarmīn muestran además en el anverso la expresión "Califa de Allah", es decir, el título utilizado por Abd alMalik en este periodo, aunque no llevan expresamente su nombre. Y los de las ciudades de Qinnasrīn, Halab (Aleppo), Qūrus y Jibrīn, pertenecientes al mismo

${ }^{52} \mathrm{~J}$. Walker, A Catalogue of the Muhammadan Coins in the British Museum II, A Catalogue of Arab-Byzantine and Post-Reform Umaiyad Coins, London, 1956, p. xxiii.

${ }^{53}$ Stefan HEIDEMAN, “The Standing Caliph-Type...”, op. cit., p. 26.

${ }^{54}$ En árabe la palabra QUTB significa literalmente axis (eje), polo. Hay una expresión que pretende definir al Qutb. Se dice de él que es kâin bâin, una criatura diferenciada. Quiere decir que es un hombre como todos los demás y a la vez se distingue de ellos por su profundidad. Cuando se le preguntó por él a ar-Râzi dijo en una ocasión: "Es un hombre entre los hombres, distinto de ellos"; y en otra ocasión dijo: "Ha nacido como hombre, pero se ha diferenciado". También se ha dicho que es mortal en su cuerpo, pero eterno en sus acciones, en sus esencias y en su mundo interior.

55 Wolfgang SCHULZE, "Symbolism on the Syrian Standing Caliph Copper Coins. A contribution to the discussion", en A. ODDY (ed.): Coinage and History in the Seventh Century Near East II, Proceedings of the $12^{\text {th }}$ Seventh Century Syrian Numismatic Round Table held at Gonville and Caius College, Cambridge on 4th and 5th April 2009 (2010), pp. 11-21, p. 21. 
jund, llevan por el contrario en su anverso el nombre del califa (li'Abd Allah'Abd al-Malik amir al-mu'minin (Para el sirviente de Allah, Abd al-Malik, Príncipe de los creyentes).

La escasa calidad de las monedas de este jund en general, hizo pensar a Clive Foss ${ }^{56}$ en una rápida producción motivada quizá por la intensa actividad militar, y en la posibilidad de que fueran las primeras con la tipología del califa en pie que se labraron en Siria.

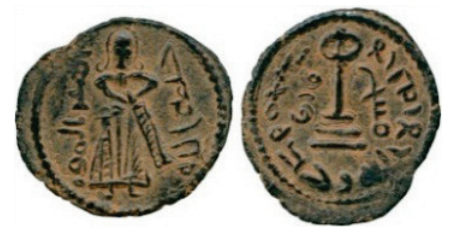

Fig. 32 .

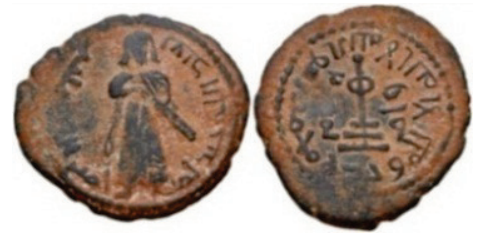

Fig. 34.

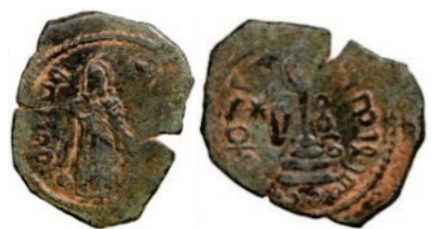

Fig. 33 .

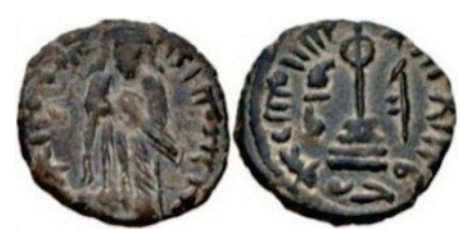

Fig. 35 .

JUND QUINNASRIN: Fig. 32. Felús de Manbij. Fig. 33. Felús de Ma'arrat Masrin. Fig. 34. Felús de Qinnasrīn. Fig. 35. Felús de Halab (Aleppo).

En las cecas pertenecientes al jund Damasco (Damasco, Ammān, y Heliopolis (Baalbek), los feluses llevan tanto en la leyenda de anverso como de reverso el comienzo de la Profesión de fe y el de la Misión Profética de Mahoma (lā ilaha illā Allāh wah̆dahu, Muhammad rasūl Allāh - "No hay dios sino Allah sólo él, Mahoma es el enviado de Allah"), precedida a veces de la fórmula de invocación "Bismi Allāh"). La imagen del califa suele presentar además aquí una cabeza más grande que en el resto de las cecas y el poste sobre gradas del reverso es bastante más corto también.

En Damasco capital, las emisiones del "califa de pie" comprenden además dos variantes o sub-grupos, determinados por el tipo del reverso. El primero de ellos muestra un corto poste rematado por el signo $\Phi$ de gran tamaño (fig. 37) y el segundo presenta el poste un poco más largo, atravesado por dicho signo pero rematado por una flecha (fig. 38). Además, estos feluses suelen contener erratas en sus leyendas, lo que parece indicar que la producción de moneda de bronce no estuvo tan controlada y supervisada como la de oro por la administración del califa. En Ammān existen asimismo feluses de dos tipos. Uno de ellos también lleva

${ }^{56}$ Clive FOSS, Arab-Byzantine Coins... op. cit., pp. 76-77. 
en el reverso un corto poste atravesado por el signo $\Phi$ de gran tamaño (fig. 39), mientras que el otro conserva en el reverso la gran letra $\mathrm{M}$ del follis bizantino (fig. 40).

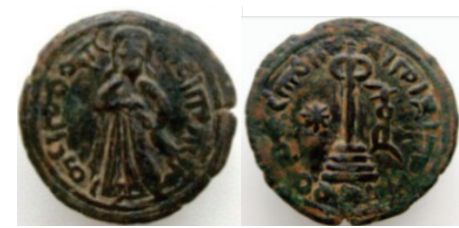

Fig. 36.

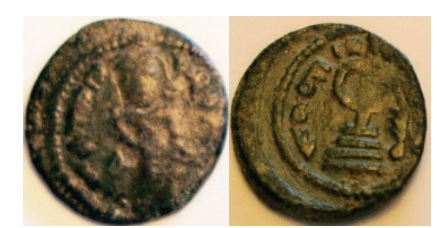

Fig. 37.

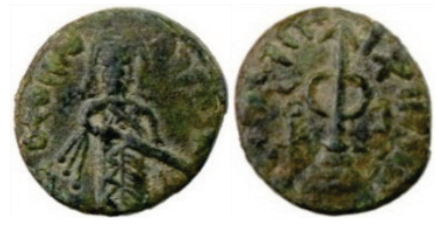

Fig. 38.

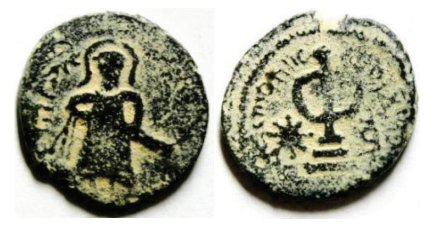

Fig. 39.

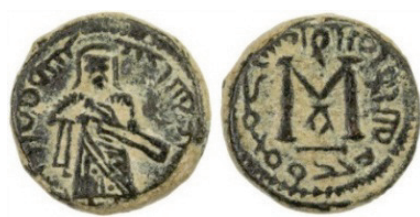

Fig. 40.

JUND HIMS o HOMS: Fig. 36. Felús de Hims (Emesa). JUND DAMASCO: Fig. 37. Felús de Damasco. Fig. 38. Felús de Damasco. Fig. 39. Felús de Amman. Fig. 40. Felús atribuido a Amman.

En el jund Al-Jazira, en Mesopotamia, las emisiones de bronce parece que fueron bastante escasas, conservándose en la actualidad pocos ejempla$\mathrm{res}^{57}$. Su tipología consistió asimismo en la imagen del califa de pie en el anverso y en el poste sobre escalones en el reverso atravesado por el símbolo $\Phi$. En el taller de Al-Ruha, los feluses llevan en el anverso la inscripción: Muhammad - rasūl allah (Mahoma - es el enviado de Allah") a ambos lados del califa, y en el reverso: "lā ilaha illā allah wah̆dahu muhammad rasūl allah", precedida "Bismi Allāh". En cuanto a Harran (fig. 42), la leyenda del anverso consiste en el nombre Muhammad a la izquierda y Harrān a la derecha del califa, y en el reverso, a la izquierda del poste rematado por el símbolo $\Phi$, aparece el monograma griego th y a la derecha Muhammad.

Clive Foss y R.G. Hoyland ${ }^{58}$ pensaban que los bronces de Al-Jazira podían mostrar la imagen del propio Mahoma y no la del califa Abd al-Malik, teoría que en la actualidad no parece contar con muchos seguidores.

${ }^{57}$ Las emisiones de Al-Jazira fueron estudiadas en profundidad en: Ingrid and Wolfgang SCHULZE, "The Standing Caliph Coins of al-Jazira: some problems and suggestions", en The Numismatic Chronicle, 170 (2010), pp. 331-352.

${ }^{58}$ Clive FOSS, Arab-Byzantine Coins... op. cit.,pp. 67 y 69. R. G. HOYLAND, "Writing the biography of the prophet Muhammad: problems and solutions", History Compass 5/2 (2007), pp. 581-602. 


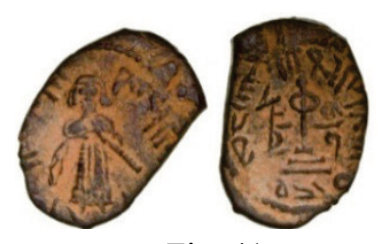

Fig. 41.

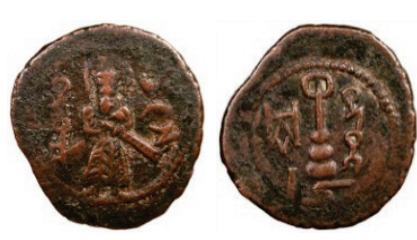

Fig. 42.

JUND AL-URDUNN: Fig. 41. Felús de Tabariya. JUND AL-JAZIRA: Fig. 42. Felús de Harran.

Finalmente, en las monedas de las ciudades pertenecientes al jund Filastin (Iliya, Yubna y Ludd) (figs, 43, 44, 45), la imagen del califa del anverso se combina con la leyenda "Mahoma es el enviado de Allah", mientras que en el reverso figuran únicamente el nombre de la ceca y el del jund a ambos lados de la letra $\mathbf{m}$. Respecto a la presencia de dicha letra en los feluses de este jund, como argüía Wolfang Schulze ${ }^{59}$ es muy probable que Abd al-Malik tuviera en cuenta el predominio del Cristianismo allí, por lo que fue el único lugar en donde decidió mantener dicha letra, evitando así que las monedas con el símbolo islámico pudiesen ser rechazadas allí.

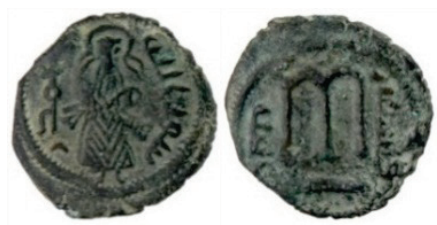

Fig. 43.

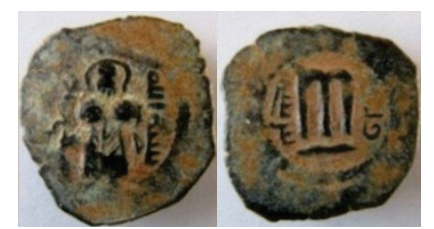

Fig. 44.

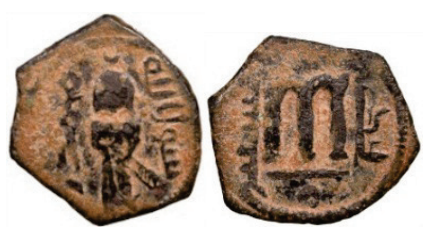

Fig. 45.

JUND FILASTIN: Fig. 43. Felús de Iliya (Jerusalén). Fig. 44. Felús de Yubnā (Yobna). Fig. 45. Felús de Luud.

\section{LA GRAN REFORMA MONETARIA DE ABD AL-MALIK: EL NA- CIMIENTO DE LA MONEDA “EPIGRÁFICA” (77 H. / 696 d. C.)}

En algún momento del año 77 H. / 696 d. C., parece ser que Abd al-Malik inició su segunda y gran reforma monetaria, dando lugar al nacimiento de la moneda árabe "anicónica", caracterizada por la presencia de leyendas arábigas en ambos lados. La aparición de una moneda completamente "epigráfica" era algo totalmente innovador, que respondió no sólo al impulso propagandístico de extender la religión islámica, sino a un claro deseo de Abd al-Malik de emitir un tipo de moneda unificada, capaz de circular y de ser aceptada en todo el Imperio Islámico, cit., p.19.

${ }^{59}$ Wolfgang SCHULZE, "Symbolism on the Syrian Standing Caliph Copper Coins...”, op. 
desde Siria, la Península Arábiga y Egipto, hasta los territorios orientales de Irán e Irak.

Los motivos que le impulsaron a introducir esta importante modificación en este momento no parecen estar del todo claros. Varios siglos después, ciertos historiadores y eruditos árabes como Ibn al-Athir ${ }^{60}$ o Abu Hilâl al-'Askari ${ }^{61}$, señalaban que fue el sabio Khalid ibn Yazid Ibn Muawiya ${ }^{62}$ quien, ante la amenaza del emperador bizantino de acuñar sólidus ofensivos al Islam (al haber introducido Abd al-Malik la Profesión de fe musulmana y la mención a Mahoma en sus dinares y dirhemes), le aconsejó que dejase de utilizar los sólidus bizantinos y que acuñase un nuevo tipo de moneda que mencionase a Allah. Y así fue como se labraron los nuevos dinares y dirhemes.

La modificación se efectuó además durante el breve e impopular reinado del emperador Leoncio (695-698 d. C.), quien, tras organizar un golpe de estado, había conseguido deponer a Justiniano II, finalizando así su primer reinado. A comienzos del reinado de Leoncio los árabes conquistaron el norte de África y el poder bizantino experimentó un acusado declive. Por lo tanto, en mi opinión es posible que Abd al-Malik aprovechase esta situación para emitir su nuevo tipo de moneda, y fue cuando decidió que los musulmanes deberían tener sus propias monedas.

Los antiguos dinares con su representación califal en el anverso, fueron reemplazados por otros de peso algo más reducido, que mostraban dos leyendas en ambas caras, una marginal, y otra central dispuesta en varias líneas. Las leyendas fueron íntegramente religiosas, desapareciendo además el nombre del califa por completo. En la leyenda marginal del anverso o I. Área, figuraría a partir de ahora en los dinares la Misión Profética de Mahoma completa: "Mahoma es el enviado de Allah, enviole con la dirección y religión verdadera para hacerla manifiesta sobre todas las religiones, aunque conciban odio los politeístas", mientras que en la leyenda central se mostraba la Profesión de fe árabe: "No hay Dios sino / Allah,

\footnotetext{
${ }^{60}$ Ibn al-Athir fue un historiador y biógrafo árabe que se dedicó al estudio de la historia y de la tradición islámica; vivió entre 1160 y 1233 d. C. Ibn al-Athir. "Mention of Striking the Islamic Dirhams and Dinars; Year 76 AH.”, Translated by Fawzan Barrage (en http://islamiccoins. ancients.info/umayyads/readingumayyadcoins.htm) [consultado el 25/ 05/2015].

${ }^{61}$ Erudito islámico fallecido en el año 1005 d. C. El testimonio de este autor, recogido en su obra Kitab as-sinaatain (Libro de las dos artes), se encuentra en: http://www.history-sciencetechnology.com/articles/articles\%2012.html\#_edn16 )[consultado el 25/ 05/2015].

${ }^{62}$ Khalid Ibn Yazid Ibn Muawiyah era hermano de Moawiya II, y por tanto fue príncipe Omeya. Su especial interés por las ciencias y por la alquimia, y su labor como traductor de obras del griego y copto al árabe, le granjearon el sobrenombre del "Sabio de la familia de Marwan". Falleció en el año 85 H. / 704 d. C.
} 
sólo él / no hay compañero para él". En la II Área o reverso, llevarían en su leyenda marginal la frase: "En el nombre de Allah" junto con los datos técnicos de la pieza "fue acuñado este dinar en la ceca de... el año..." y en la leyenda central, la Sura 112 del Corán incompleta y en tres líneas: “Allah es uno, Allah / es eterno, no engendró / ni fue engendrado" (fig. 46).

Los dirhemes llevaban prácticamente las mismas leyendas que los dinares, aunque con diferente distribución. En la leyenda marginal del anverso o I. Área era donde figuraba la invocación a Allah, la fecha y el lugar en el que había sido acuñada la pieza: "En el nombre de Allah fue acuñado este dírham en...(ceca) en el año...", mientras que en la II. Área era donde se mostraba la Misión Profética de Mahoma ("Mahoma es el enviado de Allah, envióle con la dirección y religión verdadera para hacerla manifiesta sobre todas las religiones, aunque conciban odio los politeístas"). En cuanto a las leyendas centrales, éstas eran prácticamente semejantes a las de los dinares, aunque la del reverso o II. Área mostraba la Sura 112 del Corán completa en cuatro líneas (fig. 47): “Allah es uno, Allah / es eterno, no engendró / ni fue engendrado / y no hay para él igual alguno".

Tras introducir los nuevos dinares, Abd al-Malik dictó un decreto convirtiendo a dichas piezas en las únicas permitidas y oficiales de oro de los territorios omeyas. Las monedas tanto bizantinas como árabe-bizantinas anteriores, se recogieron para el Tesoro real, con la intención de ser fundidas y reacuñadas.

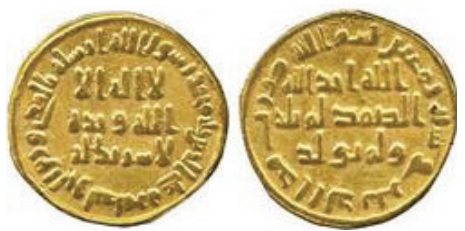

Fig. 46.

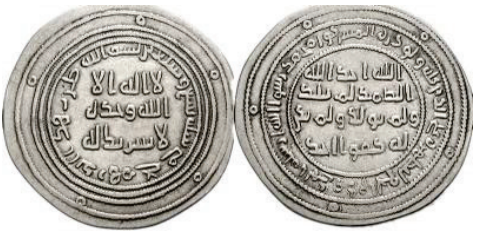

Fig. 47.

Fig. 46. Dinar Omeya de la reforma monetaria de Abd al-Malik. Fig. 47. Dírham Omeya de la reforma monetaria de Abd al-Malik.

Como observó Luke Treadwel ${ }^{63}$, la creación de una moneda estrictamente "epigráfica" por Abd Al-Malik se considera un signo de que sus administradores fueron incapaces de elaborar una iconografía numismática o un vocabulario visual apropiado para representar al estado Islámico. La imagen del rey persa, utilizada hasta entonces en las emisiones árabe-sasánidas de Irán e Irak, no podía mantenerse en una moneda que pretendía expresar mediante sus diseños la unidad del nuevo régimen bajo la religión del Islam y que circularía también en los territorios de Siria.

${ }^{63}$ Luke TREADWELL, “Abd al-Malik's Coinage Reforms...”, op. cit., p. 377. 
En cuanto a la imagen califal y la del símbolo sobre escalones que recordaba a la cruz sobre escalones bizantina, utilizada durante la fase transicional en las monedas de Siria, tampoco podía seguir utilizándose en acuñaciones pensadas para su circulación en Irán. Este tipo de imaginería era extraña a la cultura visual iraní y además habría sido incomprensible para los musulmanes de allí. Por otra parte Luke Treadwel ${ }^{64}$, siguiendo a Bates y Blair, opina que la imagen califal en las monedas en la etapa transicional, debió provocar una fuerte oposición generalizada por parte de la comunidad musulmana, pues de otro modo no habría sido abandonada tan pronto.

Todos estos problemas debieron ser los que obligaron a Abd al-Malik en el 77 H. / 696 d. C. a rechazar los experimentos iconográficos de los últimos cinco años, con el abandono de la imaginería figurativa en favor de una moneda sin imágenes. La acuñación epigráfica que aprobó en su Reforma Monetaria de dicho año, tenía muchas ventajas sobre la acuñación transicional.

Los nuevos diseños de las monedas (las propias leyendas centrales y marginales), transmitían un mensaje sumamente claro que impedía cualquier tipo de ambigüedad, promovían la reforma del lenguaje que el califa había iniciado en su cancillería $^{65}$ y establecían además un modelo uniforme sencillo, que intentaba sustituir la plétora de emisiones de plata de los numerosos gobernadores (muchas de las cuales conservaban aún los nombres de los gobernadores Zubairires) que circulaban en Irán. Al eliminar al propio califa de las monedas, sustituían el carácter real de dicha imagen por una acuñación teocrática, apropiada para un gobernante que definía su papel como representante de Allah.

Y no sólo fue su imagen, sino que el propio nombre del califa desapareció también de las monedas, no volviendo a aparecer de manera oficial hasta comienzos de la época Abasí. Finalmente, al mostrar en sus dos lados distintos versos del Corán, las monedas árabes expresaban directamente el mensaje del Islam, convirtiéndose en "misioneros" individuales de la fe.

A diferencia de lo ocurrido con el oro y con la plata, las monedas de bronce arábigas no resultaron ni unificadas ni homogeneizadas tras la reforma de Abd alMalik $^{66}$. Las emisiones de feluses de la post-reforma fueron además esencialmente

${ }^{64}$ Ibídem, p. 377.

${ }^{65}$ No hay que olvidar que entre las numerosas reformas efectuadas por Abd al-Malik para centralizar el control califal, convirtió al árabe en el idioma oficial de la administración, reemplazando al griego y al persa.

66 Lutz ILISCH, "'Abd al-Malik's Monetary Reform in Copper and the Failure of Centralization", en Money, Power and Politics in Early Islamic Syria: A Review of Current Debates (ed. by Professor John HALDON), Princeton University, 2010, pp. 125-147. 


\section{MARÍA DEL MAR ROYO MARTÍNEZ

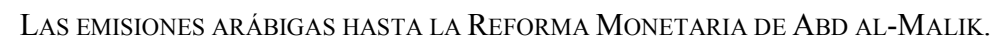

locales, siendo acuñados sobre todo por gobernadores y oficiales locales. Sus diseños, pesos, módulos, e incluso la extensión de sus leyendas, fueron enormemente variados en contraposición con los de los dinares y los dírhems completamente unificados, existiendo así una gran diversidad de piezas. Todo ello, unido a su escaso atractivo en comparación con las monedas de oro y de plata, ha hecho que en la actualidad continuemos algo escasos de estudios y que sigamos planteándonos numerosos interrogantes en relación con dichas emisiones ${ }^{67}$.

Aunque algunos feluses llevaron a partir de la reforma de Abd al-Malik la Shadada ("No hay dios sino Allah, Mahoma es el enviado de Allah") o parte de ella, así como una parte de la Profesión de fe o Kalima ("No hay dios sino Allah, sólo él, no hay compañero para él) y de la Misión Profética de Mahoma ("Mahoma es el enviado de Allah, envióle con la dirección y religión verdadera...”), además del nombre de la ceca, e incluso el año de emisión, otros muchos carecerán de algunos de esos elementos. Por otra parte, y a diferencia de los nuevos dinares y dirhemes, en bastantes piezas de bronce se mantuvieron durante un buen tiempo diferentes motivos figurativos, así como algunos nombres de los gobernadores que los acuñaron, junto a los de las cecas.

La acuñación de cobre califal era de especial importancia para el aspecto ideológico de la reforma, puesto que era una moneda que llegaba a todos los niveles de la población. Y dado que la imagen del califa había sido rechazada por parte de la comunidad islámica, en los casos en los que se mantuvieron las imágenes figurativas, éstas consistieron fundamentalmente en representaciones de tipo astral, geométrico, o bien asociadas a la naturaleza, tales como la estrella, el creciente, peces, aves, roedores, diferentes frutos, palmeras, etc., como las que se ilustran a continuación.

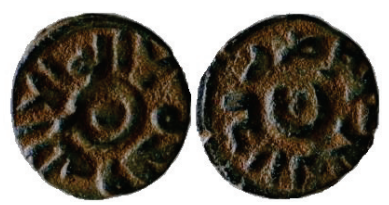

Fig. 48.

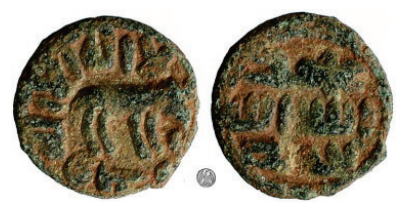

Fig. 49.

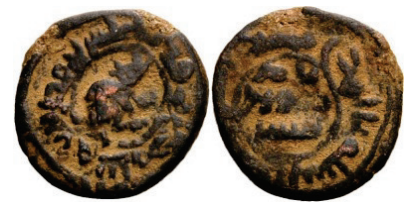

Fig. 50.

Fig. 48. Felús Omeya de Hims (Jund Hims), Anverso: Círculo con punto en su interior. Alrededor, leyenda marginal.- Reverso: Medio círculo o creciente, con un punto en su interior. Alrededor, leyenda marginal. Fig. 49. Felús Omeya de Hims (sin fecha).- Anverso: Bestia o elefante a la derecha. Alrededor leyenda marginal. Reverso: Leyenda central. Fig. 50. Felús Omeya de Hims

${ }^{67}$ Esta observación fue realizada hace ya varias décadas por Carolina DOMÉNECH BELDA, "Circulación monetaria de época emiral en el País Valenciano: el problema de las primeras emisiones en cobre", en IX Congreso Nacional de Numismática, Elche, 1994, pp. 281-302. En la actualidad, y a pesar del prolongado tiempo transcurrido, el catálogo más completo sobre los feluses emitidos tras la reforma de Abd al-Malik, continúa siendo el del Walker: John R. WALKER, A Catalogue of the Arab-Byzantine and Post-reform Umaiyad Coins, London, 1956. 
(sin fecha).- Anverso: Jerbo hacia la derecha. Alrededor, leyenda marginal. Reverso: Leyenda central. Alrededor leyenda marginal.

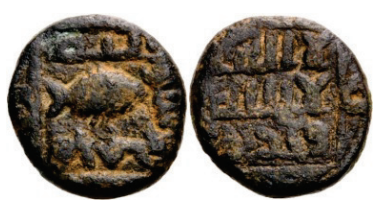

Fig. 51.

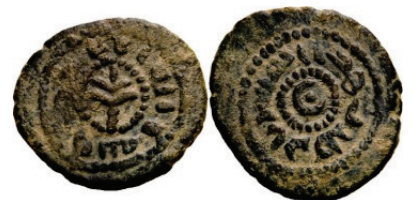

Fig. 52.

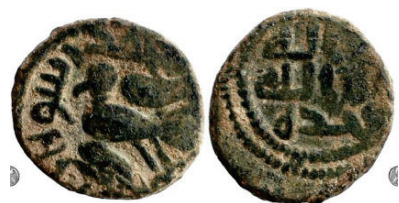

Fig. 53.

Fig. 51. Felús Omeya emitido probablemente en Baysan (sin fecha).- Anverso: Pez hacia la derecha. Alrededor y en disposición cuadrada, leyenda marginal.- Reverso: Leyenda central. Alrededor y en disposición cuadrada leyenda marginal. Fig. 52. Felús Omeya de Al-Ramla (Jund Filastin).- Anverso: Palmera. Alrededor, leyenda marginal. Reverso: Creciente dentro de un círculo punteado. Alrededor leyenda marginal. Fig. 53. Felús Omeya de ceca incierta de Filastin (Palestina).- Anverso: Pájaro hacia la izquierda. Alrededor leyenda marginal. Reverso: Leyenda central.

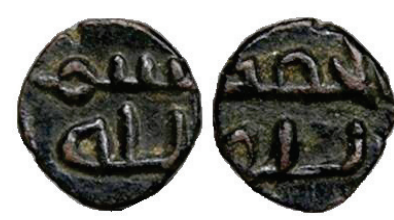

Fig. 54

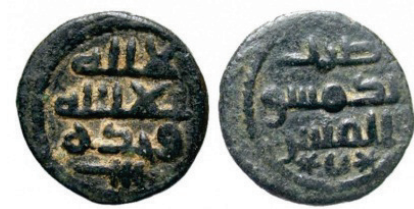

Fig. 55.

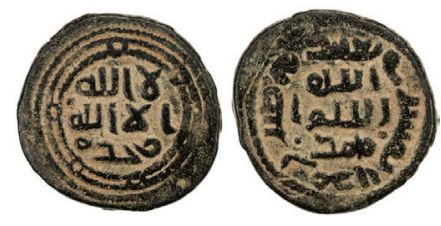

Fig. 56.

Fig. 54. Felús Omeya emitido en alguna ceca del norte de África, Anverso: Leyenda central.Reverso: Leyenda central. Fig. 55. Felús Omeya de Damasco. Fig. 56. Felús Omeya de Baalbek. 